\title{
Oncidiinae (Orchidaceae) on the great curve of the Xingu River, Pará state, Brazil
}

\author{
Carneiro-Silva, $M Q{ }^{a}$, Koch, $A K .^{b}$, Viana, $P L .^{c}$ and Ilkiu-Borges, $A L .{ }^{c *}$ \\ aPrograma de Pós-Graduação em Ciências Biológicas, Botânica Tropical, Museu Paraense Emílio Goeldi, \\ Universidade Federal Rural da Amazônia - UFRA, Av. Perimetral, 1901, Terra Firme, CEP 66077-830, Belém, PA, Brazil \\ búcleo de Pesquisa Orquidário do Estado, Instituto de Botânica de São Paulo, \\ Av. Miguel Stéfano, 3687, Água Funda, CEP 04301-902, São Paulo, SP, Brazil

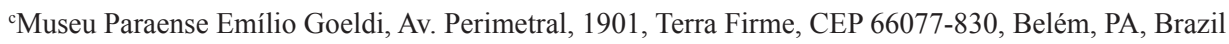 \\ *e-mail: ilkiu-borges@museu-goeldi.br
}

Received: May 30, 2014 - Accepted: February 10, 2015 - Distributed: August 31, 2015

(With 3 figures)

\begin{abstract}
Among the studies on Orchidaceae in the Amazon, none comprised the region of the Great Curve of the Xingu River, located in the lower Xingu river. The aim of this study was to inventory and taxonomically study the species of Oncidiinae (Orchidaceae) in the Great Curve of the Xingu River, Pará state. The floristic survey was performed in the area of the Belo Monte hydroelectric plant, in the Vitória do Xingu municipality, centrally inserted in the called Great Curve of the Xingu River. Botanical collections were accomplished between June 2011 and December 2013. A total of 27 species of Oncidiinae, distributed in 15 genera, was inventoried in the study area. Notylia Lindl. and Trichocentrum Poepp. \& Endl. were the richest genera, with five and four species, respectively, followed by Erycina Lindl., Ionopsis Kunth, Lockhartia Hook., Macradenia R.Br., and Ornithocephalus Hook., with two species each. The remaining eight genera are represented by a single species each in the study area. Morphological descriptions, a key for taxonomic identification, illustrations, and comments on distribution, ecology, phenology and morphology are provided for all inventoried species.
\end{abstract}

Keywords: Eastern Amazônia, Cymbidieae, Epidendroideae, orchids, taxonomy.

\section{Oncidiinae (Orchidaceae) na volta grande do Rio Xingu, Pará, Brasil}

\section{Resumo}

Entre os estudos com Orchidaceae na Amazônia, nenhum compreende a região da Volta Grande do rio Xingu, localizada no baixo Xingu. O objetivo deste estudo foi inventariar e estudar taxonomicamente as espécies de Oncidiinae (Orchidaceae) na Volta Grande do rio Xingu, estado do Pará, Brasil. O levantamento florístico foi realizado na área da Usina Hidrelétrica de Belo Monte, no município de Vitória do Xingu, inserido centralmente na chamada Volta Grande do Xingu. Foram realizadas coletas botânicas entre junho de 2011 e dezembro de 2013. Na área de estudo, foram inventariadas 27 espécies de Oncidiinae, distribuídas em 15 gêneros. Notylia Lindl. e Trichocentrum Poepp. \& Endl. foram os mais ricos, com cinco e quatro espécies respectivamente, seguidos por Erycina Lindl., Ionopsis Kunth, Lockhartia Hook., Macradenia R.Br., e Ornithocephalus Hook., com duas espécies cada. Os oito gêneros restantes estão representados na área de estudo por uma única espécie. São fornecidas descrições morfológicas, chave taxonômica para identificação, ilustrações e comentários sobre distribuição, ecologia, fenologia e morfologia para todas as espécies inventariadas.

Palavras-chave: Amazônia Oriental, Cymbidieae, Epidendroideae, orquídeas, taxonomia.

\section{Introduction}

The Oncidiinae (Orchidaceae, Epidendroideae, Cymbidieae) includes more than 1600 species in 61 genera and is one of the most diverse subtribes of the Orchidaceae (Dressler, 1993; Chase et al., 2003). This heterogeneous group has a broad morphological diversity of floral and vegetative structures (Chase et al., 2003; Neubig et al., 2012) and the widest range of chromosomes numbers known for Orchidaceae, with a noticeable variation in genome size (Chase et al., 2005; Neubig et al., 2012). The species inhabit different environments and, hence, have a great diversification of pollination systems (Dressler, 1993; Papadopulos et al., 2013). Neotropical forests are usually 
rich in Oncidiineae species, which grow from the sea level to almost 4000 m.s.m, in the Andean mountain chain (Dressler, 1993; Chase et al., 2003; Neubig et al., 2012).

Typically, Oncidiinae species are epiphytes, although some can be terrestrial or rupiculous (Dressler, 1993; Chase et al., 2003); leaves are distichous, conduplicate and/or equitant, articulate or not, cylindrical or laterally compressed; inflorescences are lateral, simple or branched, with one to several flowers. The flowers can be ressupinate or not; labellum can present a menthum or calcar, and usually have a callus of several distinct shapes. In general, lateral inflorescence, the presence of a conspicuous callus in the labellum, and two cartilaginous pollinia with a short viscidium and long stipe are distinguishing features of the Oncidiinae (Dressler, 1993).

Recent molecular phylogenies focusing the Oncidiinae provided support for several taxonomic rearrangements in generic circumscriptions of the subtribe (Sosa et al., 2001; Williams et al., 2001a, b). Almost all Brazilian species traditionally placed in Oncidium Sw. (Pabst and Dungs, 1977; Hoehne, 1949; Congniaux, 1904, 1905, 1906) were transferred to Gomesa R.Br. (Williams et al., 2001a) and other small genera, such as Baptistonia Barb Rodr., Binotia Rolfe, Ornithophora Barb. Rodr., Rodrigueziella Kuntze and Rodrigueziopsis Schltr. (Chase et al., 2009; Penha and Catharino 2010). A single species, Oncidium baueri Lindl., remains in the Brazilian flora (Barros et al., 2014), following Chase et al. (2009) sensu stricto circumscription of Oncidium (Neubig et al., 2012).

Floristic surveys of Orchidaceae performed in Pará state revealed Oncidiinae as one of the richest subtribes, as in results of Cardoso et al. (1995), Medeiros and Jardim (2011), Silveira et al. (1995), von Atzingen et al. (1996) and Koch et al. (2014). Although a detailed inventory of the Orchidaceae in the Great Curve of Xingu River region has never been accomplished, Ilkiu-Borges and Cardoso (1996) recorded 40 species of Orchidaceae in the called Xingu microregion, a much wider region which encompasses at least part of this study area.

The region known as the Great Curve of Xingu River, is located in the lower Xingu river (Ab'Sáber, 1996). The dominant vegetation types are evergreen lowland dense rainforest, evergreen lowland open rainforest, and open forests dominated by palms, but less than $40 \%$ of the original vegetation in the region of the Great Curve of the Xingu River remains preserved (Salomão et al., 2007). At present, the area is under the influence of the construction of Belo Monte hydroelectric plant.

Given the lack of an accurate floristic survey in the region, this work aims to inventory and taxonomically study the species of Oncidiinae (Orchidaceae) in the Great Curve of the Xingu River, Pará state. Morphological descriptions, a key for taxonomic identification, illustrations, and comments on distribution, ecology, phenology and morphology are provided for all inventoried species.

\section{Material and Methods}

The floristic survey was performed in the area of the Belo Monte hydroelectric plant (0322'00”S / 51 56 '00”W), in the Vitória do Xingu municipality (Figure 1), centrally inserted in the called Great Curve of the Xingu River (Ab’Sáber, 1996).

The climate is Am, according to Koopen's classification, with average temperature of $26^{\circ} \mathrm{C}$, annual precipitation $2.289 \mathrm{~mm}$ and average relative humidity ranging from $78 \%$ to $88 \%$ (Sousa-Júnior et al., 2006).

Four main types of phytophysiognomies are found in the study area: evergreen dense rainforest, riverine evergreen rainforest, evergreen lowland open rainforest, and open palm dominated forests (Salomão et al., 2007). The vegetation in the region is widely fragmented due to the history of human occupation, based on several types of land use and extractivism (Salomão et al., 2007).

Samples examined in this study were, in part, obtained from the project "Survey and Scientific exploitation of the Flora of the UHE Belo Monte", which is part of the Basic Environment Plan of the Norte Energia S.A. company. The samples were regularly collected from June 2011 to December 2013 by the team of the mentioned project. Additionally, three field expeditions to the study area were done by the first author for further collections, which were herborised according to usual techniques. Additional information for the species, such as phenology, habit, habitat, and photographs were also annotated during the field work.

Sterile specimens were collected and kept until blooming in the greenhouse of the Environmental Studies Centre (CEA) of the Norte Energia S.A. company and, then, herborised. The specimens were deposited in the Herbarium MG, of the Museu Paraense Emílio Goeldi, and flowers were preserved in liquid media (alcohol 70\%, water $25 \%$ and glycerin $5 \%$ ).

Species identification, taxonomic updating and classification were based on pertinent literature (Rodrigues, 1877, 1882; Congniaux, 1893-1896, 1898-1902, 1904, 1905, 1906; Hoehne, 1949; Pabst and Dungs, 1975, 1977; Dunsterville and Garay, 1959, 1961, 1965, 1972, 1979; Rodrigues et al., 1996; Chase et al., 2003; Neubig et al., 2012), as well as by the collaboration of experts in taxonomy of Orchidaceae.

Morphological terminologies follow Radford et al. (1974), Gonçalves and Lorenzi (2011), and with pertinent literature for Orchidaceae. All information provided in the description was based on the examined specimens. Author names abbreviations are according to Brummitt and Powell (1992). The genus circumscriptions are in accordance with Govaerts et al. (2014).

Illustrative plates were elaborated based on the diagnostic floral charts prepared for the collected specimens. These were digitalised and edited on GIMP 2.8 software.

\section{Results and Discussion}

A total of 27 species of Oncidiinae, distributed in 15 genera, was inventoried in the study area. Notylia Lindl. and Trichocentrum Poepp. \& Endl. were the richest genera, with five and four species, respectively, followed by Erycina Lindl., Ionopsis Kunth, Lockhartia Hook., 


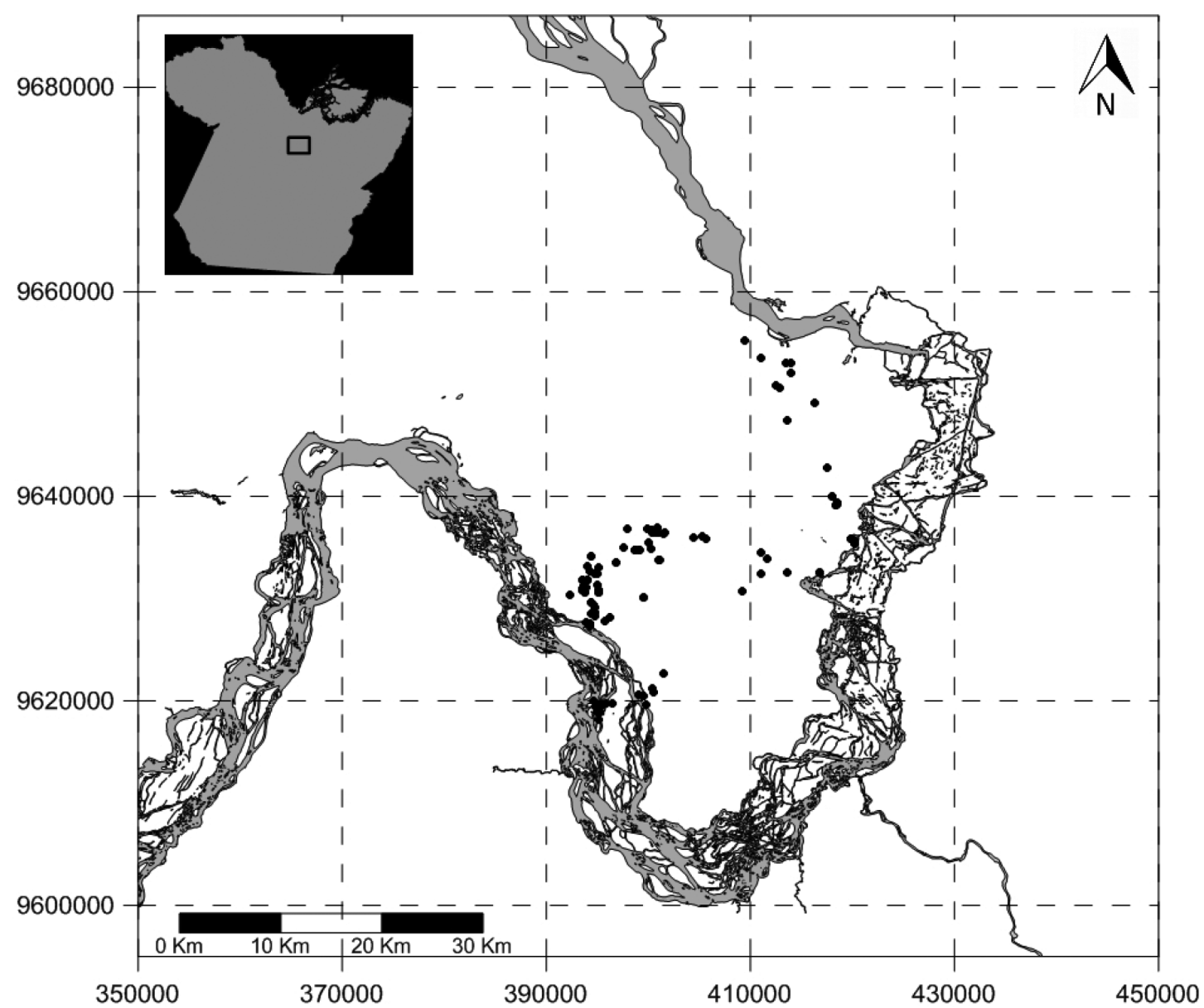

Figure 1. Study area with sampling points.

Macradenia R.Br., and Ornithocephalus Hook, with two species each. The remaining eight genera are represented by a single species each.

\subsection{Key for identification of the Oncidiinae species from the great curve of the Xingu River}

1. Plants with caulome thickened into pseudobulb .....2

1'. Plants with caulome not thickened into a pseudobulb.

2. Leaves terete. .3

2'. Leaves flattened or ensiform .5

3. Inflorescence $40-180 \mathrm{~cm}$ long; lateral sepals free........ ..Trichocentrum cebolleta

3'. Inflorescence 6-23 cm long; lateral sepal fused on its $1 / 2$ proximal portion or more.

4. Labellum ca. $7 \times 3 \mathrm{~mm}$, apex truncate, slightly apiculate...... .Ionopsis satyrioides

4'. Labellum ca. $4 \times 2$ mm, apex acute, reflexed.................................Quekettia microscopica
5. Pseudobulb apex unifoliate. .6

5'. Pseudobulb apex with 2 or 3 leaves

6. Leaves $1.4-2.5 \times 0.4-0.7 \mathrm{~cm}$, ensiform

.Caluera tavaresii

6'. Leaves $2.5-20 \times 1-4 \mathrm{~cm}$, flattened........................

7. Inflorescence a panicle......................................... 8

7'. Inflorescence a raceme..........................................

8. Inflorescence ca. $3-10 \mathrm{~cm}$ long; flowers ca. $0.6 \mathrm{~cm}$ wide. Trichocentrum morenoi

8'. Inflorescence ca. 40-130 cm long; flowers ca. $1.5 \mathrm{~cm}$ wide. .Ionopsis utricularioides

9. Flowers calcarate. .10

9'. Flowers without a calcar. .11

10. Inflorescence with 1-5-flowers; lateral sepals free..... ..Trichocentrum fuscum

10'. Inflorescence with 16-35-flowers; lateral sepals completely fused. Rodriguezia lanceolata 
11. Pseudobulbs without lateral leaves. .12

11'.Pseudobulbs with one or two lateral leaves.... .15

12. Column with clinandrium margins entire Trichocentrum nanum

12'. Column with clinandrium margins fimbriate. .13

13. Labellum apex rounded and subapiculate Trichopilia mutica

13'. Labellum apex narrow laminar. .14

14. Labellum with lateral lobes rounded, with three longitudinal carenas Macradenia lutescens

14'. Labellum with lateral lobes narrow acuminate, with one longitudinal carena ........Macradenia multiflora

15. Lateral sepals not falcate; labellum suborbicular to oblong Notylia peruviana

15'. Lateral sepals falcate or nearly so; labellum sagittate or cordate . .16

16. Labellum sagittate; carena pubescent

..Notylia yauaperyensis

16'. Labellum cordate to subcordate; carena glabrous ....

17. Flower ca. $7 \mathrm{~mm}$ wide Notylia lyrata

17'. Flower ca. $9 \mathrm{~mm}$ wide 18

18. Lateral sepals fused on the half proximal portion; labellum ca. $5 \times 2.4 \mathrm{~mm}$ .Notylia barkeri

18'. Lateral sepals free or nearly so; labellum ca. $6 \times 2 \mathrm{~mm}$ Notylia sp.

19. Inflorescence racemose, ca. 6-35 cm long .20

19'. Inflorescence paniculate, ca. 100-200 cm long ......... Oncidium baueri

20. Inflorescence 1-3-flowered; lateral sepals 28-30 $\times$ 6-7 $\mathrm{mm}$ Aspasia variegata

20'. Inflorescence with 7-12 flowers; lateral sepals ca. $145 \times 8 \mathrm{~mm}$ Brassia chloroleuca

21. Plants ca. $8-28 \mathrm{~cm}$ long .22

21'. Plants smaller, ca. 2.5-8 cm long .23

22. Labellum with lateral lobes narrow-winged, subpatent to arching ..................Lockhartia lunifera

22'. Labellum with lateral lobes inconspicuous

.Lockhartia imbricata

23. Leaves with an equitant sheath ..... .24

23'. Leaves sheaths not equitant .26

24. Pollinia two ........Macroclinium wullschlaegelianum

24'. Pollinia four .25
25. Flower ca. $0.8 \mathrm{~cm}$ wide; labellum with trichomes and papillae Ornithocephalus gladiatus

25'. Flowers ca. $0.4 \mathrm{~cm}$ wide; labellum glabrous ..Ornithocephalus bicornis

26. Flower ca. $1.2 \mathrm{~cm}$ wide; callus of labellum crested fimbriate or ciliate Erycina glossomystax

26'. Flower ca. $1.7 \mathrm{~cm}$ wide; callus of labellum crested and glabrous ..Erycina pusilla

Aspasia variegata Lindl., Edwards's Bot. Reg. 22: t. 1907 (1836) (Figure 2a).

Plants 15-30 cm long; caulome thickened into pseudobulb, 4.5-6 $\times 1.5-2.3 \mathrm{~cm}$, ellipsoid, slightly oblique, laterally compressed, apex 1-2-foliate. Leaves 9-22 × 1.5-2.3 cm, flat, linear-oblanceolate, green, apex acuminate. Inflorescence a raceme, 6-10 cm long, lateral, 1-3-flowered; peduncle $5-10 \mathrm{~cm}$ long. Flowers $4-4.5 \mathrm{~cm}$ wide; pedicel plus ovary 25-28 mm long; dorsal sepal 28-30 × 6-7 mm, lanceolate, slightly cymbiform, green, striate or purplish-brown maculate, apex acuminate rostrate; lateral sepals 28-30 × 6-7 mm, lanceolate, slightly cymbiform, free, green, striate or purplish-brown maculate, apex acuminate, rostrate and slightly oblique; petals ca. $25 \times 8 \mathrm{~mm}$, oblong-ovate, subpatent, green, purplish-brown striate, slightly yellow at margin, apex acuminate, slightly rostrate; labellum ca. $15 \times 20 \mathrm{~mm}$, calcar absent, 3-lobed, sessile, white with purple grooves, callus with two keels; column ca. $20 \mathrm{~mm}$ long, subterete, clinandrium margins erose; pollinia 2. Fruit 7-8 $\times 0.8-1 \mathrm{~cm}$, fusiform.

Specimens examined: Brazil. Pará: Vitória do Xingu, UHE Belo Monte, Sítio Pimental, 02-12-2011, fl., PSACF 32 (MG); ibid., 21-10-2011, fl., PSACF 04 (MG); ibid., Sítio Canais e Diques, 17-12-2012, fl., PSACF 770 (MG).

Aspasia variegata occurs in Trinidad, Venezuela, Guiana, Suriname and Brazil (Dunsterville and Garay, 1959; Pabst and Dungs, 1977). In Brazil, it is known from the states of Amapá, Amazonas, Pará, Rondônia, Roraima, Tocantins, Distrito Federal, Goiás, Mato Grosso, Maranhão and Rio de Janeiro (Barros et al., 2014). In Pará, it was recorded in the Serra dos Carajás (Silveira et al., 1995), Serra das Andorinhas (von Atzingen et al., 1996), Ilha do Combu (Medeiros and Jardim, 2011) and Caxiuanã National Forest (Koch et al., 2014). In the study area, A. variegata was found growing in secondary forests, blooming in January, May, June, October and December.

Aspasia variegata is characterised by its ellipsoid, laterally compressed and oblique pseudobulbs, inflorescences shorter than the leaves, with 1-3 flowers, and a patent labellum, which is fused with the column on its half base.

Additional illustrations: Congniaux (1905, tab. 43, fig. III), Hoehne (1949, tab. 257, fig. II) and Dunsterville and Garay (1979, p. 14).

Brassia chloroleuca Barb.Rodr., Gen. Spec. Orchid. 1: 97 (1877) (Figure 2b).

Plants 14-40 cm long; caulome thickened into pseudobulb, $6-13 \times 2-3.6 \mathrm{~cm}$, ellipsoid, laterally compressed, apex 2-foliate. Leaves $17-20 \times 3.5-5.3 \mathrm{~cm}$, flat, oblanceolate 
or elliptic, dark green, apex acute. Inflorescence a raceme, 18-35 cm long, lateral, 7-12-flowered; peduncle 9-18 cm long. Flowers 14-16 cm wide; pedicel plus ovary $15-18 \mathrm{~mm}$ long; dorsal sepal ca. $65 \times 7 \mathrm{~mm}$, linear-oblanceolate, greenish-yellow with purplish-brown spots at base, apex strongly acuminate; lateral sepals ca. $145 \times 8 \mathrm{~mm}$,
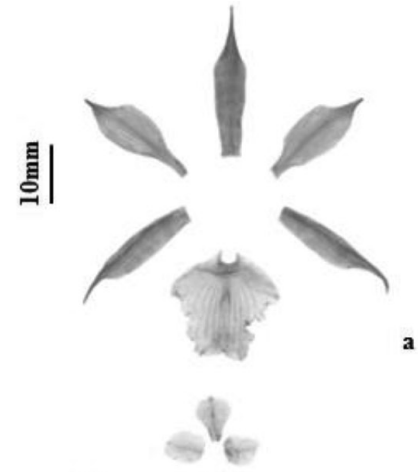

罡
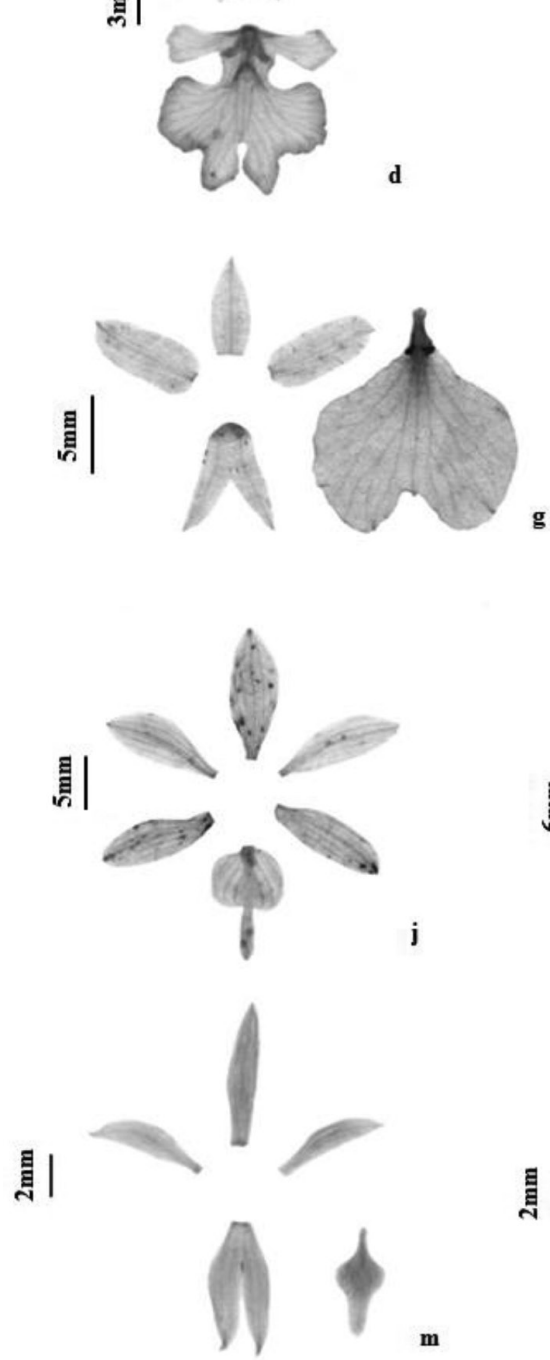
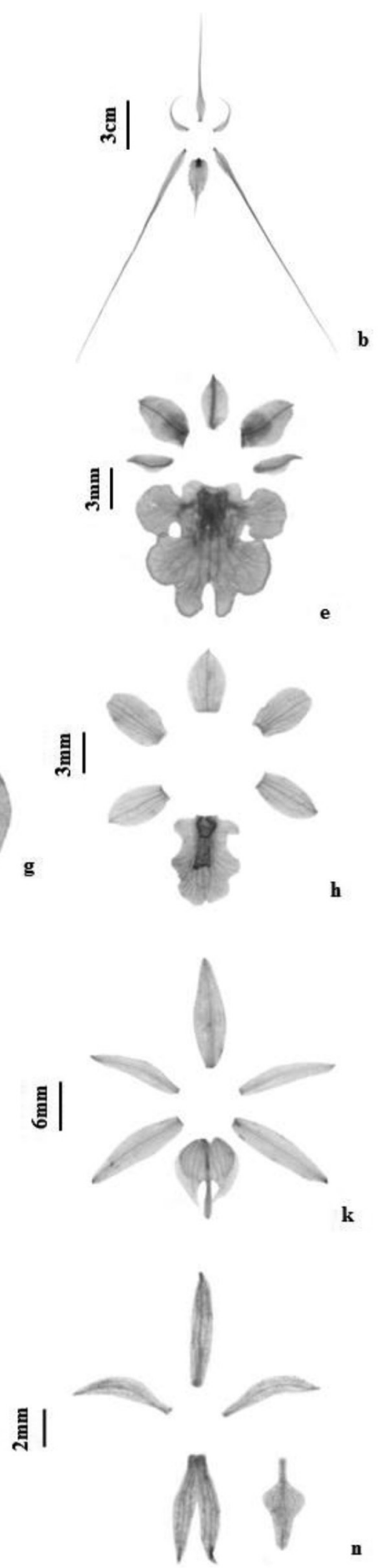
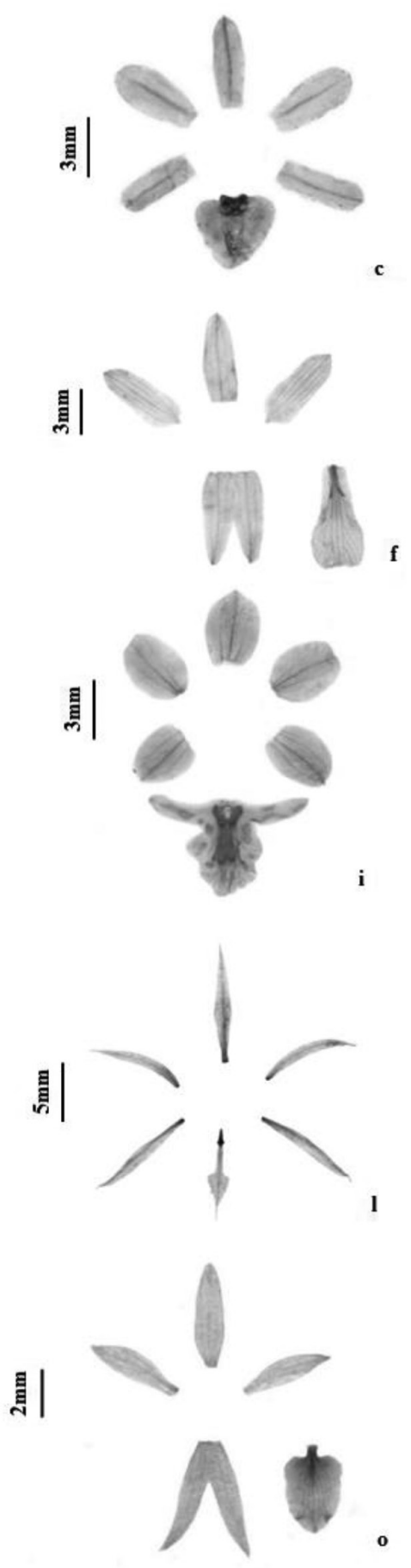

Figure 2. (a-o) Perianth pieces of Oncidiinae (Orchidaceae) species from the Great Curve of Xingu River. (a) Aspasia variegata Lindl. (b) Brassia chloroleuca Barb.Rodr. (c) Caluera tavaresii Campacci \& J.B.F.Silva. (d) Erycina glossomystax (Rchb.f.) N.H.Williams \& M.W.Chase. (e) Erycina pusilla (L.) N.H.Williams \& M.W.Chase. (f) Ionopsis satyrioides (Sw.) Rchb.f. (g) Ionopsis utricularioides (Sw.) Lindl. (h) Lockhartia imbricata (Lam.) Hoehne. (i) Lockhartia lunifera (Lindl.) Rchb.f. (j) Macradenia lutescens R.Br. (k) Macradenia multiflora (Kraenzl.) Cogn. (1) Macroclinium wullschlaegelianum (H.Focke) Dodson. (m) Notylia barkeri Lindl. (n) Notylia lyrata S.Moore. (o) Notylia peruviana (Schltr.) C.Schweinf. 
linear-oblanceolate, strongly filiform, free, greenish-yellow with purplish-brown spots at base, apex acuminate; petals ca. $30 \times 5 \mathrm{~mm}$, linear-lanceolate, greenish-yellow with purplish-brown spots at base, apex acuminate; labellum ca. $37 \times 14 \mathrm{~mm}$, calcar absent, entire, ovate, pale yellow with purplish-brown spots at base, callus with one pair of acute callus and other pair of keels; column ca. $7 \mathrm{~mm}$ long, terete, clinandrium margins entire; pollinia 2. Fruit ca. $5.6 \times .3 .8 \mathrm{~cm}$, ellipsoid.

Specimens examined: Brazil. Pará: Vitória do Xingu, UHE Belo Monte, Sítio Pimental, 18-05-2012, fl., PSACF 228 (MG); ibid., Sítio Pimental, Ilha Marciana, 20-07-2012, fl., PSACF585 (IAN); ibid., Sítio Canais and Diques, 22-05-2012, fr. PSACF 238 (MG); ibid., Sítio Canais e Diques, igarapé Paquiçamba, 29-05-2012, fl., PSACF 277 (MG); ibid., Sítio Canais e Diques, igarapé Paquiçamba, 30-05-2012, fl., PSACF 284 (IAN); ibid., Sítio Canais e Diques, Leste Oeste direita, 20-06-2012, fl., PSACF425 (IAN); ibid., Sítio Belo Monte, 30-12-2011, fl., PSACF48 (MG).

It is endemic to Brazil, known from the states of Amazonas, Maranhão, Pará, Roraima, and Mato Grosso (Silva et al., 1995; Barros et al., 2014). In Pará, it was recorded on the Ilha do Combu (Medeiros and Jardim, 2011). The species is quite common in the study area, occurring in evergreen forest formations, and was observed blooming from March to August.

Brassia chloroleuca is easily recognized among other orchids in the study area by its inflorescences with conspicuous flowers (up to 12 flowers) with narrow sepals, especially the lateral ones, which can reach $14 \mathrm{~cm}$ long.

Additional illustrations: Hoehne (1949, tab. 259), Rodrigues et al. (1996, tab. 320), and Silva and Silva (2011).

Caluera tavaresii Campacci \& J.B.F. Silva, Colet. Orquídeas Brasil. 6: 182 (2008) (Figure 2c).

Plants 2-3 cm long; caulome slightly thickened into pseudobulb, ca. $0.25 \times 0.15 \mathrm{~cm}$, cylindrical, not laterally compressed, apex 1-foliate. Leaves 1.4-2.5 × 0.4-0.7 cm, ensiform, suboblongate or oblanceolate, oblique, purple-green, apex acute or acuminate. Inflorescence umbeliform, 3-5.5 cm long, lateral, 4-5-flowered; peduncle 2.3-4.5 cm long. Flowers ca. $0.7 \mathrm{~cm}$ wide; pedicel plus ovary ca. $6 \mathrm{~mm}$ long; dorsal sepal ca. $4.5 \times 1.5 \mathrm{~mm}$, oblong, white or purple, apex obtuse, subapiculate; lateral sepals ca. $4.4 \times 1.5 \mathrm{~mm}$, oblongate, free, white or purple, apex obtuse and subapiculate; petals ca. $4.5 \times 2 \mathrm{~mm}$, oblanceolate, white or purplish transluced, apex rounded or retuse; labellum ca. $4 \times 4 \mathrm{~mm}$, calcar absent, entire, cordate, white or purplish translucent, coppery at base, callus with subcordate and high callus; column ca. $3 \mathrm{~mm}$ long, subterete, clinandrium margins not seen; pollinia 4. Fruit ca. $0.8 \times 0.6 \mathrm{~cm}$, ellipsoid.

Specimens examined: Brazil. Pará: Vitória do Xingu, UHE Belo Monte, Sítio Canais e Diques, 28-06-2013, fl., PSACF 20130628.10H01 (MG).

Caluera tavaresii is endemic to Brazil, only known by the type specimen from Oriximiná, state of Pará (Barros et al., 2014; Govaerts et al., 2014). This is, therefore, the second record of this rare species. It was found in forests in regeneration, blooming in June and July.

The species is remarkable by its short size, ensiform leaves, and umbelliform inflorescences, consisting of 4-5 flowers with a cordate labellum.

Erycina glossomystax (Rchb.f.) N.H.Williams \& M.W.Chase, Lindleyana 16: 136 (2001) (Figure 2d).

Plants ca. $3 \mathrm{~cm}$ long; caulome not thickened into pseudobulb. Leaves 1.6-2.7 $\times$ 0.3-0.5 cm, ensiform, linearoblong, green, apex acute, rare obtuse. Inflorescence a raceme, 1.5-2.5 cm long, axilar, 1-2-flowered; peduncle $1-1.5 \mathrm{~cm}$ long. Flowers ca. $1.2 \mathrm{~cm}$ wide; pedicel plus ovary ca. $6 \mathrm{~mm}$ long; dorsal sepal ca. $3 \times 3 \mathrm{~mm}$, suborbicular to obovate, pale green, apex subapiculate; lateral sepals ca. $3 \times 1.5 \mathrm{~mm}$, linear-lanceolate, slightly connate at the base, pale green, apex acuminate; petals ca. $3 \times 2 \mathrm{~mm}$, oblongate, pale green with purple blotches at base, apex slightly apiculate; labellum ca. $10 \times 9 \mathrm{~mm}$, calcar absent, 6-lobed, pale green with purple blotches at base, callus with frimbiated ou ciliated crests; column ca. $2 \mathrm{~mm}$ long, inconspicuous, clinandrium margins entire; pollinia 2. Fruit not seen.

Specimens examined: Brazil. Pará: Vitória do Xingu, UHE Belo Monte, CEA, 01-10-2013, fl., PSACF 20131001.13H09 (MG).

Erycina glossomystax occurs in Tropical America (Govaerts et al., 2014), from Mexico to Brazil, where it is known for the states of Acre, Amazonas, Pará, Rondônia, Bahia, Maranhão, Espírito Santo, and Rio de Janeiro (Pabst and Dungs, 1977; Barros et al., 2014). In Pará state, it was recorded in Serra dos Carajás (Silveira et al., 1995) and Serra das Andorinhas (von Atzingen et al., 1996). In the study area, E. glossomystax was collected in disturbed areas, usually growing as epiphyte on twigs of shrubs and small trees. It was found with flowers in July, August and October.

Erycina glossomystax is, at first glance, similar to E. pusilla by its typical small size, equitant leaves and few flowered inflorescences, but it can be distinguished by its typically ciliate or deeply denticulate callus in the labellum (vs. callus glabrous and with entire margins in E. pusilla).

Additional illustrations: Congniaux (1905, tab. 62, fig. II), and Dunsterville and Garay (1979, p. 875).

Erycina pusilla (L.) N.H.Williams \& M.W.Chase, Lindleyana 16: 136 (2001) (Figure 2e).

Plants ca. $2.5 \mathrm{~cm}$ long; caulome not thickened into pseudobulb. Leaves $1.5-2 \times 0.3-0.5 \mathrm{~cm}$, ensiform, linear-oblong, green, apex acute, rare obtuse. Inflorescence a raceme, 2-3.3 cm long, axilar, 1-2-flowered; peduncle 1.6-2.2 cm long. Flowers ca. $1.7 \mathrm{~cm}$ wide; pedicel plus ovary ca. $7 \mathrm{~mm}$ long; dorsal sepal ca. $4 \times 3 \mathrm{~mm}$, obovate, pale green, apex rounded, abaxialy apiculate; lateral sepals ca. $4.5 \times 1.5 \mathrm{~mm}$, linear-lanceolate, free, pale green, apex acuminate and oblique; petals ca. $6 \times 4 \mathrm{~mm}$, oblongate, pale green with purple blotches at base, apex retuse, abaxially apiculate; labellum ca. $16 \times 15 \mathrm{~mm}$, calcar absent, 6-lobed, pale green with purple blotches at base, callus with entire 
crests; column ca. $3.5 \mathrm{~mm}$ long, inconspicuous, clinandrium margins entire; pollinia 2. Fruit ca. $1 \times 0.8 \mathrm{~cm}$, ellipsoid.

Specimens examined: Brazil. Pará: Vitória do Xingu, UHE Belo Monte, Sítio Canais e Diques, 11-11-2011, fl., PSACF 17 (MG).

Distributed from Mexico to Brazil (Govaerts et al., 2014; Pabst and Dungs, 1977), where it was recorded in Acre, Amazonas, Amapá, Pará, Rondônia, Roraima, Bahia, Ceará, Maranhão, Pernambuco, Sergipe, Goiás, Mato Grosso, Minas Gerais, and Rio de Janeiro (Pabst and Dungs, 1977; Barros et al., 2014). In Pará, it was collected in Serra dos Carajás (Silveira et al., 1995) and in the present study area, where it was found blooming in August, October and November.

Morphological affinities with E. glossomystax were discussed under the latter species.

Additional illustrations: Congniaux (1905, tab. 62, fig. I), Hoehne (1949, tab. 235. Fig. III), and Dunsterville and Garay (1979, p. 876).

Ionopsis satyrioides (Sw.) Rchb.f. in W.G.Walpers, Ann. Bot. Syst. 6: 683 (1863) (Figure 2f).

Plants 5-15 cm long; caulome slightly thickened into pseudobulb, $0.6-1 \times 0.3-0.5 \mathrm{~cm}$, cylindrical, not laterally compressed, apex 1-foliate. Leaves 4-12 × 0.2-0.3 cm, terete, with 1 longitudinal groove, brownish-green, apex acute or acuminate. Inflorescence a raceme or panicle, 6-18 cm long, lateral, 3-8-flowered; peduncle $2-7 \mathrm{~cm}$ long. Flowers $0.5-0.6 \mathrm{~cm}$ wide; pedicel plus ovary ca. $6 \mathrm{~mm}$ long; dorsal sepal ca. $6 \times 2.5 \mathrm{~mm}$, oblong, whitish, apex rounded, subapiculate; lateral sepals ca. $6 \times 4 \mathrm{~mm}$, oblongate, connate at the half basal portion, whitish, apex acute; petals ca. $5.5 \times 2 \mathrm{~mm}$, oblongate, whitish with two purplish grooves, apex acute; labellum ca. $7 \times 3 \mathrm{~mm}$, slightly calcarate, entire, obovate, whitish with purple lines from the yellow base, callus with two lamellar keels; column ca. $3 \mathrm{~mm}$ long, claviform, clinandrium margins entire; pollinia 2. Fruit ca. $1 \times 0.6 \mathrm{~cm}$, oblongoid.

Specimens examined: Brazil. Pará: Vitória do Xingu, UHE Belo Monte, Sítio Canais e Diques, 17-11-2011, fl., PSACF 25 (MG); ibid., Sítio Canais e Diques, 09-02-2013, fl., PSACF 937 (MG); ibid., CEA, 01-10-2013, fl., PSACF 20131001.13H11(MG).

Ionopsis satyrioides is widely distributed in Tropical America and West Indies, with records for Colombia, Guiana, Panama, Suriname, and Venezuela (Dunsterville and Garay, 1959; Werkhoven, 1986; Govaerts et al., 2014). In Brazil, it occurs in Amazonas, Pará and Maranhão (Silva et al., 1995; Barros et al., 2014) states, with records for Serra dos Carajás (Silveira et al., 1995) and Serra das Andorinhas (von Atzingen et al., 1996) in Pará. It was collected in secondary forests and disturbed areas in the study area, blooming in January, February and October.

Ionopsis satyrioides can be easily distinguished from I. utricularioides by its terete leaves, cylindrical pseudobulbs and inflorescences never longer than $18 \mathrm{~cm}$, with whitish translucent flowers. Ionopsis utricularioides has flat linear-lanceolate leaves, subcylindrical pseudobulbs and inflorescences 40-130 cm long, with flowers pinkish to purplish.

Additional illustrations: Dunsterville and Garay (1959, p. 345).

Ionopsis utricularioides (Sw.) Lindl., Coll. Bot.: t. 39A (1826) (Figure 2g).

Plants 10-18 cm long; caulome thickened into pseudobulb, 1-3 × 0.4-0.7 cm, cylindrical, not laterally compressed, apex 1-foliate. Leaves 8-16 × 1-1.5 cm, flat, linerar-lanceolate, green or greenish-red, apex acuminate. Inflorescence a panicle, $40-130 \mathrm{~cm}$ long, lateral, 50-200-flowered; peduncle $25-80 \mathrm{~cm}$ long. Flowers ca. 1.5 $\mathrm{cm}$ wide; pedicel plus ovary ca. $6 \mathrm{~mm}$ long; dorsal sepal ca. $6 \times 3 \mathrm{~mm}$, ovate to oblanceolate, pinkish or purplish with dark veins, apex acuminate; lateral sepals ca. $6 \times 4 \mathrm{~mm}$, oblanceolate, connate at the half basal portion, pinkish or purplish with dark veins, apex acuminate; petals ca. 6 $\times 3 \mathrm{~mm}$, oblongate, pinkish or purplish with dark veins, apex acute; labellum ca. $14 \times 14 \mathrm{~mm}$, slightly calcarate, 2-lobed, pinkish or purplish with dark veins, withish base, callus with one pair of lamelar keels and another pair of orbiculated callus; column ca. $3 \mathrm{~mm}$ long, claviform, clinandrium margins entire; pollinia 2 . Fruit ca. $2.5 \times 1.1$ $\mathrm{cm}$, oblongoid.

Specimens examined: Brazil. Pará: Vitória do Xingu, UHE Belo Monte, Sítio Canais e Diques, Leste Oeste direita, 10-05-2012, fl., PSACF 209 (MG).

A quite common neotropical species, distributed from the south of Flórida (United States), north of México to Tropical America (Dunsterville and Garay, 1959; Pabst and Dungs, 1977; Govaerts et al., 2014). In Brazil, it was recorded in Acre, Amazonas, Pará, Rondônia, Bahia, Maranhão, Pernambuco, Sergipe, Distrito Federal, Goiás, Mato Grosso do Sul, Mato Grosso, Minas Gerais, Rio de Janeiro, São Paulo, Paraná, and Santa Catarina (Pabst and Dungs, 1977; Silva et al., 1995; Barros et al., 2014). In Pará, the species was registered in the Serra dos Carajás (Silveira et al., 1995), Serra das Andorinhas (von Atzingen et al., 1996) and in the present study area, where it was collected in secondary vegetation, blooming between February and May.

Morphological comparison with I. satyrioides is presented under the latter species.

Additional illustrations: Hoehne (1949, tab. 242), Dunsterville and Garay (1979, p. 364) and Rodrigues et al. (1996, tab. 41).

Lockhartia imbricata (Lam.) Hoehne, Arq. Bot. Estado São Paulo, n.s., f.m., 2: 139 (1952) (Figure 2h).

Plants 8-28 cm long; caulome not thickened into pseudobulb. Leaves 1.3-2 × 0.3-0.7 cm, ensiform, triangular, bilaterally imbricate, green, apex obtuse. Inflorescence cymose, ca. $1.5 \mathrm{~cm}$ long, axilar, 1-2-flowered; peduncle ca. $0.5 \mathrm{~cm}$ long. Flowers ca. $1 \mathrm{~cm}$ wide; pedicel plus ovary 10-13 mm long; dorsal sepal ca. $4 \times 3 \mathrm{~mm}$, suborbicular, cymbiform, yellow, apex acuminate or apiculate; lateral sepals ca. $5 \times 2.5 \mathrm{~mm}$, elliptic, free, yellow, apex acuminate; petals ca. $5.1 \times 2 \mathrm{~mm}$, obovate, yellow, apex rounded; labellum ca. $6 \times 4 \mathrm{~mm}$, calcar absent, 5-6-lobed, yellow 
with brown maculae, callus with one subglobose keel and other small crests; column ca. $2 \mathrm{~mm}$ long, inconspicuous, clinandrium margins entire; pollinia 2. Fruit ca. $1.5 \times 0.9 \mathrm{~cm}$, oblongoid.

Specimens examined: Brazil. Pará: Vitória do Xingu, UHE Belo Monte, Sítio Pimental, 31-08-2012, fl., PSACF 704 (MG); ibid., Sítio Canais and Diques, Leste Oeste direita, 27-07-2012, fl., PSACF 627 (MG); ibid., Sítio Canais and Diques, 22-05-2013, fl., PSACF 1253 (MG); ibid., Sítio Canais and Diques, 30-07-2013, fl., PSACF 20130730.13H02 (MG); ibid., Sítio Belo Monte, 20-09-2013, fl., PSACF 20130920.10H02 (MG).

Lockhartia imbricata is distributed throughout Tropical America, from Mexico to Brazil (Pabst and Dungs, 1977; Werkhoven, 1986; Govaerts et al., 2014). In Brazil, it was recorded in Acre, Amazonas, Amapá, Pará, Rondônia and Mato Grosso (Barros et al., 2014). In the study area, it is a common species and was found growing in evergreen dense forests and secondary vegetation, blooming from May to November.

Lockhartia imbricata can be distinguished of L. lunifera in the study area mainly by the size of lateral lobes of labellum, which are smaller in L. imbricata $(4 \mathrm{~mm})$ when compared to L. lunifera ( $8 \mathrm{~mm})$.

Additional illustrations: Dunsterville and Garay (1979, p. 438) and Silva and Silva (2011, p. 296).

Lockhartia lunifera (Lindl.) Rchb.f., Bot. Zeitung (Berlin) 10: 767 (1852) (Figure 2i).

Plants 10-26 cm long; caulome not thickened into pseudobulb. Leaves 1.5-2.6 $\times 0.5-0.8 \mathrm{~cm}$, ensiform, triangular, bilaterally imbricate, green, apex obtuse. Inflorescence cymose, ca. $1.5 \mathrm{~cm}$ long, axillary, 1-2-flowered; peduncle ca. $0.5 \mathrm{~cm}$ long. Flowers ca. $1 \mathrm{~cm}$ wide; pedicel plus ovary ca. $10 \mathrm{~mm}$ long; dorsal sepal ca. $4 \times 3 \mathrm{~mm}$, suborbicular to elliptic, cymbiform, yellow, apex subobtuse, apiculate; lateral sepals ca. $4 \times 3 \mathrm{~mm}$, suborbiculate or elliptic, free, yellow, apex subobtuse, subapiculate; petals ca. $4 \times 3 \mathrm{~mm}$, suborbiculate or elliptic, yellow, apex rounded or retuse; labellum ca. $5 \times 8 \mathrm{~mm}$, calcar absent, 5-6-lobed, yellow with brown grooves and maculae, callus with one subglobose callus with trichomes and two keels crested; column ca. $3 \mathrm{~mm}$ long, inconspicuous, clinandrium margins entire; pollinia 2. Fruit ca. $1.5 \times 0.9 \mathrm{~cm}$, oblongoid.

Specimens examined: Brazil. Pará: Vitória do Xingu, UHE Belo Monte, Sítio Canais e Diques, TR 27, 04-11-2011, fl., PSACF 15 (MG).

Although endemic to Brazil, Lockhartia lunifera presents a widespread distribution, occurring in Amapá, Amazonas, Pará, Alagoas, Bahia, Maranhão, Pernambuco, Sergipe, Espírito Santo, Rio de Janeiro, São Paulo, Paraná, Rio Grande do Sul, and Santa Catarina (Pabst and Dungs, 1977; Silva et al., 1995; Barros et al., 2014; Govaerts et al., 2014). In Pará, it is known from Serra dos Carajás (Silveira et al., 1995), Serra das Andorinhas (von Atzingen et al., 1996) and in the present study area, inhabiting evergreen dense forests and secondary vegetation, blooming in April, June, and November.
A comparison between Lockhartia lunifera and L. imbricata is provided under the latter species.

Additional illustrations: Hoehne (1949, tab. 280).

Macradenia lutescens R.Br., Bot. Reg. 8: t. 612. (1822) (Figure 2j).

Plants 14-15 cm long; caulome thickened into pseudobulb, $3-5 \times 0.7-1.4 \mathrm{~cm}$, subpyriform to cylindrical, not laterally compressed, apex 1-foliate. Leaves $8.5-10 \times 2-2.5 \mathrm{~cm}$, flat, lanceolate or oblong, dark green, apex acute or acuminate. Inflorescence a raceme, ca. $8 \mathrm{~cm}$ long, lateral, 3-7-flowered; peduncle ca. $3.5 \mathrm{~cm}$ long. Flowers ca. $1.5 \mathrm{~cm}$ wide; pedicel plus ovary ca. $10 \mathrm{~mm}$ long; dorsal sepal ca. $10 \times 5 \mathrm{~mm}$, elliptic, cymbiform, orange to yellow, apex acuminate; lateral sepals ca. $10 \times 3 \mathrm{~mm}$, oblongate or oblanceolate, free, orange to yellow, apex acuminate; petals ca. $8 \times 4 \mathrm{~mm}$, oblongate or oblanceolate, orangish-yellow with purple spots, apex acuminate; labellum ca. $9 \times 7 \mathrm{~mm}$, calcar absent, 3-lobed, pinkish-white with purplish grooves, callus with three longitudinal keels; column ca. $6 \mathrm{~mm}$ long, subterete, clinandrium margins fimbriate; pollinia 2. Fruit not seen.

Specimens examined: Brazil. Pará: Vitória do Xingu, UHE Belo Monte, Sítio Pimental, 15-01-2013, fl., PSACF 20130115.03E01 (MG);

Macradenia lutescens is distributed from Southern Florida (United States) to Tropical America (Dunsterville and Garay, 1961; Werkhoven, 1986; Govaerts et al., 2014). The knowledge on the distribution in Brazil not accurate, but it is as far known in the Amazon phytogegraphic domain (Barros et al., 2014). The record in the study area is the first of $M$. lutescens in Pará state, being found growing in evergreen dense riverine forests, where it is quite rare. The species was found blooming in a greenhouse in July, August, September, October and November.

Although not easily differentiated by vegetative features, the two Macradenia species recorded in the study area (M. lutescens and M. multiflora) can be distinguished from each other by the number and the color of the flowers and the shape of the labellum lateral lobes. Macradenia lutescens has 3-7 flowers, which are yellowish to orange, with petals presenting purple spots, and lateral lobes of the labellum rounded. In turn, M. multiflora has inflorescences with 12-26 flowers, which are purplish with margins greeninsh-yellow, and labellum lateral lobes narrow acuminate.

Additional illustrations: Dunsterville and Garay (1979, p. 449).

Macradenia multiflora (Kraenzl.) Cogn. in C.F.P.von Martius \& auct. suc. (eds.), Fl. Bras. 3(6): 115 (1904) (Figure 2k).

Plants 14-17 cm long; caulome thickened into pseudobulb, 3-6 $\times 0.7-1.7 \mathrm{~cm}$, subpyriform to cylindrical, not laterally compressed, apex 1-foliate. Leaves 8-13 × 1.7-3.5 cm, flat, lanceolate or oblong, dark green, apex acute or acuminate. Inflorescence a raceme, 8-14 cm long, lateral, 12-26-flowered; peduncle ca. $3 \mathrm{~cm}$ long. Flowers ca. $2 \mathrm{~cm}$ wide; pedicel plus ovary ca. $10 \mathrm{~mm}$ long; dorsal sepal ca. $13 \times 4 \mathrm{~mm}$, lanceolate to oblanceolate, purple with greenish-yellow margin, apex acuminate; lateral sepals ca. $13 \times 4 \mathrm{~mm}$, 
oblongate or oblanceolate, free, purple with greenish-yellow margin, apex acuminate; petals ca. $12 \times 3 \mathrm{~mm}$, lanceolate, subfalcate, purplish, greenish-yellow margin, apex acuminate; labellum ca. $10 \times 9 \mathrm{~mm}$, calcar absent, 3-lobed, white with purple spots, callus with three longitudinal keels; column ca. $8 \mathrm{~mm}$ long, subterete, clinandrium margins fimbriate; pollinia 2. Fruit ca. $2.8 \times 1.3 \mathrm{~cm}$, ellipsoid.

Specimens examined: Brazil. Pará: Vitória do Xingu, UHE Belo Monte, Sítio Pimental, 03-11-2011, fl., PSACF 09 (MG); ibid., Sítio Pimental, 07-12-2011, fl., PSACF 36 (MG); ibid., Bela Vista, TR-55, 02-06-2012, fl., PSACF 424 (MG).

Occurs in Brazil and Paraguay (Govaerts et al., 2014). In Brazil, it is distributed in the states of Pará, Rondônia, Tocantins, Goiás and Mato Grosso, Minas Gerais, São Paulo and Rio Grande do Sul (Pabst and Dungs, 1977; Barros et al., 2014). It is a common species in the study area, and was found growing in evergreen dense forests and secondary forests, blooming in March, April, May, June, November and December.

Comparative morphological features between both Macradenia in the study area are under the comments provide for M. lutescens.

Macroclinium wullschlaegelianum (H.Focke) Dodson, Icon. Pl. Trop. 10: t. 939 (1984) (Figure 21).

Plants 3-5 cm long; caulome not thickened into pseudobulb. Leaves 1.3-2 × 0.4-0.6 cm, ensiform, lanceolate, green, purple reticulate, apex acuminate, oblique. Inflorescence a compacted raceme, 4-7 cm long, axillary, 6-12-flowered; peduncle $3-4.5 \mathrm{~cm}$ long. Flowers ca. $1 \mathrm{~cm}$ wide; pedicel plus ovary 10-12 mm long; dorsal sepal ca. $9 \times 2 \mathrm{~mm}$, lanceolate, subcymbiform, greenish-purple translucent, apex acuminate, apiculate; lateral sepals $8-10 \times 1.1-1.2 \mathrm{~mm}$, lanceolate, subcymbiform, slightly connate at base, greenish-purple translucent, apex acuminate; petals ca. $8 \times 1 \mathrm{~mm}$, lanceolate, subfalcate, purplish translucent with purple maculae, apex acuminate; labellum 7-8 $\times 2 \mathrm{~mm}$, calcar absent, entire, unguiculate, triangular-hastate, purplish translucent with purple maculae, callus with two auriculates crests; column ca. $10 \mathrm{~mm}$ long, filiform, clinandrium margins entire; pollinia 2. Fruit not seen.

Specimens examined: Brazil. Pará: Vitória do Xingu, UHE Belo Monte, Sítio Canais e Diques, 28-06-2012, fl., PSACF 20120628.07E02 (MG).

Macroclinium wullschlaegelianum is distributed through Central and Southern Tropical America (Govaerts et al., 2014), occurring in Venezuela, Guiana, Suriname, Brazil, Colombia, Equador and Peru (Dunsterville and Garay, 1972; Pabst and Dungs, 1977). In Brazil, it is found in Pará, Rondônia, Maranhão, Distrito Federal and Goiás. (Silva et al., 1995; Barros et al., 2014). It is rare in the study area, where it was collected in secondary forests, blooming in June, September and November.

It can be distinguished among other Oncidiinae species in the study area by its small size, leaves green, equitant, ensiform, and with purple spots, inflorescence a compacted umbelliform raceme, and a long and thin column with curved apex.
Additional illustrations: Congniaux (1904, tab. 38, fig. III), Hoehne (1949, tab. 290, fig. II) and Dunsterville and Garay (1979, p. 598).

Notylia barkeri Lindl., Edwards's Bot. Reg. 24 (Misc.): 90 (1838) (Figure 2m).

Plants 9-19 cm long; caulome thickened into pseudobulb, $2.5-4 \times 0.8-1.4 \mathrm{~cm}$, oblongoid to cylindrical, slightly laterally compressed, apex 1-foliate. Leaves 8.5-14 × 2.5-3.5 cm, flat, oblong, green, apex mucronate, oblique. Inflorescence a raceme, 10-22 cm long, lateral, ca. 80-flowered; peduncle 3-6 cm long. Flowers ca. $0.9 \mathrm{~cm}$ wide; pedicel plus ovary ca. $5 \mathrm{~mm}$ long; dorsal sepal ca. $6 \times 1.3 \mathrm{~mm}$, lanceolate, stringly cymbiform, greenish-white, apex acuminate; lateral sepals ca. $6 \times 1.2 \mathrm{~mm}$, lanceolate, cymbiform, connate at the half basal portion, greenish-white, apex apiculate, oblique, subreflexed; petals ca. $5 \times 1 \mathrm{~mm}$, oblanceolate, subfalcate, greenish-white, apex acuminate or apiculate; labellum ca. $5 \times 2.4 \mathrm{~mm}$, calcar absent, entire, unguiculate, cordate, white, callus with three longitudinal keels; column ca. $4.5 \mathrm{~mm}$ long, subterete, clinandrium margins entire; pollinia 2 . Fruit ca. $2 \times 1 \mathrm{~cm}$, ellipsoid.

Specimens examined: Brazil. Pará: Vitória do Xingu, UHE Belo Monte, Sítio Pimental, 04-11-2011, fl., PSACF 13 (MG); ibid., Sítio Pimental, 16-01-2012, fl., PSACF 66 (IAN; INPA); ibid., Sítio Canais e Diques, 19-06-2012, fl., PSACF 394/395(MG); ibid., Sítio Canais e Diques, Leste Oeste direita, 21-06-2012, fl., PSACF 440 (MG); ibid., Sítio Belo Monte, 13-01-2012, fl., PSACF 822 (MG).

Notylia barkeri occurs from México to Northern Brazil (Govaerts et al., 2014), in the states of Amazonas, Pará, Tocantins, Pernambuco, Sergipe and Mato Grosso (Pabst and Dungs, 1977; Barros et al., 2014). In Pará, there are records from Serra dos Carajás (Silveira et al., 1995) and Serra das Andorinhas (von Atzingen et al., 1996). It is quite common in disturbed places and secondary forests in the study area, where it was found blooming in January, March, April, May and June.

This species is characterised by its dense racemose inflorescence with flowers whitish-green, and a cordate labellum. The flowers in $N$. barkeri are larger than those of $N$. lyrata ( $9 \mathrm{~mm}$ vs. $7 \mathrm{~mm}$ wide), a feature that helps in the recognition of both species in the study area.

Notylia lyrata S.Moore, Trans. Linn. Soc. London, Bot. 4: 477 (1895) (Figure 2n).

Plants 7-16 cm long; caulome thickened into pseudobulb, $2-3 \times 0.6-1.2 \mathrm{~cm}$, oblongoid to cylindrical, slightly laterally compressed, apex 1-foliate. Leaves $6.5-12 \times 2-3 \mathrm{~cm}$, flat, oblong, green, apex acute. Inflorescence a raceme, 9-18 cm long, lateral, ca. 60 -flowered; peduncle ca. $3.5 \mathrm{~cm}$ long. Flowers ca. $0.7 \mathrm{~cm}$ wide; pedicel plus ovary ca. $4 \mathrm{~mm}$ long; dorsal sepal ca. $5 \times 1.1 \mathrm{~mm}$, lanceolate, cymbiform, greenish-white, apex acuminate, subreflexous; lateral sepals ca. $5 \times 1.1 \mathrm{~mm}$, lanceolate, cymbiform, connate at the half basal portion, greenish-white, apex apiculate, oblique, subreflexed; petals ca. $4.5 \times 1 \mathrm{~mm}$, linear-oblanceolate, subfalcate, greenish-white, apex acuminate or apiculate; labellum ca. $4.5 \times 2.4 \mathrm{~mm}$, calcar absent, entire, unguiculate, cordate, white or greenish-white, callus with three longitudinal 
keels; column ca. $5 \mathrm{~mm}$ long, terete, clinandrium margins entire; pollinia 2. Fruit ca. $2 \times 1 \mathrm{~cm}$, ellipsoid.

Specimens examined: Brazil. Pará: Vitória do Xingu, UHE Belo Monte, Sítio Canais e Diques, 17-11-2011, fl., PSACF 21 (MG).

Notylia lyrata is found in Paraguay and Brazil (Govaerts et al., 2014), being widespread in the latter country, with records for all regions (Pabst and Dungs, 1977; Barros et al., 2014). In the study area, it was collected in secondary forests, blooming in May.

It differs from $N$. barkeri by its shorter and wider labellum, and larger flowers, as discussed in the comments of $N$. barkeri.

Notylia peruviana (Schltr.) C.Schweinf., Bot. Mus. Leafl. 12: 205 (1946) (Figure 2o).

Plants 12-20 cm long; caulome thickened into pseudobulb, $1-2 \times 0.6-1 \mathrm{~cm}$, oblongoid, slightly laterally compressed, apex 1-foliate. Leaves 8-12 × 1.7-2 cm, flat, linear-oblong, green, apex acute. Inflorescence a raceme, 13-25 cm long, lateral, ca. 40-flowered; peduncle 3-6 cm long. Flowers $0.6-0.8 \mathrm{~cm}$ wide; pedicel plus ovary 3-4 mm long; dorsal sepal 4-5 × $1.2 \mathrm{~mm}$, oblanceolate to elliptic, cymbiform, greenish-orange, apex subacute, subrostrate; lateral sepals ca. 4.5-5 × $1.2 \mathrm{~mm}$, lanceolate or oblanceolate, connate at the half basal portion, greenishorange, apex subobtuse, apiculate, oblique, subreflexed; petals 3.2-4 × 1-1.3 mm, oblanceolate, greenish-orange, apex subacute or subrostrate; labellum 3.8-4 × 2.8-3 mm, calcar absent, entire, subunguiculate, suborbiculate or oblongate, greenish-orange, callus with three longitudinal keels; column 2-3 mm long, terete, clinandrium margins entire; pollinia 2. Fruit not seen.

Specimens examined: Brazil. Pará: Vitória do Xingu, UHE Belo Monte, Sítio Pimental, 28-03-2012, fl., PSACF 135 (MG); ibid., Sítio Canais e Diques, 09-02-2012, fl., PSACF 718 (MG); ibid., Sítio Canais e Diques, 03-03-2012, fl., PSACF 116 (MG).

Known from Guiana, Venezuela, Brazil, Bolívia, Ecuador and Peru (Dunsterville and Garay, 1965; Govaerts et al., 2014). In Brazil, it was recorded only in Pará state (Medeiros et al., 2009; Medeiros and Jardim, 2011; Barros et al., 2014). It is a common species in the study area, where it blooms in February and March.

Notylia peruviana is the most distinctive species of the genus in the study area. It can be easily recognised by its suborbicular to oblong labellum and non-falcate petals, because other congeners herein presented have a cordate (sometimes sagitate) labellum and falcate petals.

Notylia yauaperyensis Barb.Rodr., Vellosia, ed. 2, 1: 131 (1891) (Figure 3a).

Plants 7-9 cm long; caulome thickened into pseudobulb, 0.8-1 $\times 0.3-0.5 \mathrm{~cm}$, oblongoid, slightly laterally compressed, apex 1-foliate. Leaves ca. $7.5 \times 1.6 \mathrm{~cm}$, flat, linear-oblong, green, apex subacute, subapiculate. Inflorescence a raceme, 9-12 cm long, lateral, ca. 50-flowered; peduncle 2-2.5 cm long. Flowers ca. $0.7 \mathrm{~cm}$ wide; pedicel plus ovary 3-4 mm long; dorsal sepal ca. $6 \times 1 \mathrm{~mm}$, linear-lanceolate, cymbiform, white or greenish-white, apex acuminate, subreflexed; lateral sepals ca. $6 \times 2 \mathrm{~mm}$, linear-lanceolate, connate at the half basal portion, white or greenish-white, apex apiculate, oblique, reflexed; petals ca. $5 \times 1.2 \mathrm{~mm}$, linear-lanceolate or falcate, white usually with three orange maculae, apex acuminate or apiculate; labellum ca. $4.5 \times 1.5 \mathrm{~mm}$, calcar absent, entire, unguiculate, sagittate, white, callus with one longitudinal keel, pubescent; column ca. $3.5 \mathrm{~mm}$ long, terete, clinandrium margins entire; pollinia 2. Fruit not seen.

Specimens examined: Brazil. Pará: Vitória do Xingu, UHE Belo Monte, 30-05-2011, fl., PSACF 20113005. E03 (MG).

Notylia yauaperyensis occurs in French Guiana, Venezuela, Brazil and Peru (Dunsterville and Garay, 1972; Govaerts et al., 2014). In Brazil, it is restricted to the north region, with records in Amazonas, Pará and Maranhão states (Pabst and Dungs, 1977; Barros et al., 2014). In the study area it was found blooming in May and November.

It is characterised, among other species of Notylia in the study area, by its smaller vegetative size (7-9 cm long), narrower flowers, which are usually white with orange maculae in the petals, and a sagittate labellum with a pubescent kell.

Notylia sp. (Figure 3b).

Plants 9-20 cm long; caulome thickened into pseudobulb, 2-4.5 $\times 1-2 \mathrm{~cm}$, oblongoid to cylindrical, laterally compressed, apex 1-foliate. Leaves 6-15 × 2.5-4.5 cm, flat, oblong-wide, green, apex mucronate, oblique. Inflorescence a raceme, 8-20 cm long, lateral, ca. 70 -flowered; peduncle $2.5-5 \mathrm{~cm}$ long. Flowers ca. $0.9 \mathrm{~cm}$ wide; pedicel plus ovary 5-6 $\mathrm{mm}$ long; dorsal sepal ca. $8 \times 2 \mathrm{~mm}$, lanceolate, strongly cymbifom, apex acuminate; lateral sepals ca. $7 \times 2 \mathrm{~mm}$, lanceolate, cymbiform, connate at the base, greenish-white, apex apiculate, oblique, subreflexed; petals ca. $6.8 \times 1.8 \mathrm{~mm}$, oblanceolate or subfalcate, greenish-white, apex acuminate or apiculate; labellum ca. $6 \times 2 \mathrm{~mm}$, calcar absent, entire, unguiculate, subcordate, greenish-white, callus with one longitudinal keel; column ca. $5 \mathrm{~mm}$ long, terete, clinandrium margins entire; pollinia 2. Fruit not seen.

Specimens examined: Brazil. Pará: Vitória do Xingu, UHE Belo Monte, Sítio Canais e Diques, 29-05-2012, fl., PSACF 279 (MG).

This unidentified species of Notylia was found growing in open palm forests blooming in February and March.

It is morphologically related to $N$. barkeri, but it presents a typical compacted caespitose vegetative development, shorter and widely elliptic leaves, fleshy flowers, and lateral sepals fused on the base, close to the region of insertion of pedicel.

Oncidium baueri Lindl., Gen. Sp. Orchid. Pl.: 200 (1833) (Figure 3c).

Plants 30-65 cm long; caulome thickened into pseudobulb, $6.5-12 \times 3.5-5.5 \mathrm{~cm}$, ellipsoid, laterally compressed, apex 2-3-foliate. Leaves 29-44 × 2.8-3 cm, flat, lanceolate, green, apex acuminate. Inflorescence a panicle, $100-200 \mathrm{~cm}$ long, lateral, ca. 50-200-flowered; peduncle $60-150 \mathrm{~cm}$ long. Flowers ca. $2.5 \mathrm{~cm}$ wide; pedicel plus ovary $20-22 \mathrm{~mm}$ long; dorsal sepal ca. $15 \times 5 \mathrm{~mm}$, oblanceolate, greenishyellow with brown maculae, apex acuminate; lateral sepals 
ca. $16 \times 4 \mathrm{~mm}$, lanceolate or oblanceolate, oblique, free, greenish-yellow with brown maculae, apex acuminate or subobtuse; petals ca. $14 \times 5 \mathrm{~mm}$, oblanceolate or elliptic, greenish-yellow with brown maculae, apex acuminate; labellum 13-15 × 13-15 mm, calcar absent, 4-lobed, yellow with reddish-brown maculae at base, callus with several small crests; column ca. $5 \mathrm{~mm}$ long, claviform, clinandrium margins entire; pollinia 2. Fruit not seen.

Specimens examined: Brazil. Pará: Vitória do Xingu, UHE Belo Monte, 16-11-2011, fl., PSACF 20111116.02E04 (MG); ibid., 14-11-2011, fl., PSACF 20111114.02E02 (MG).
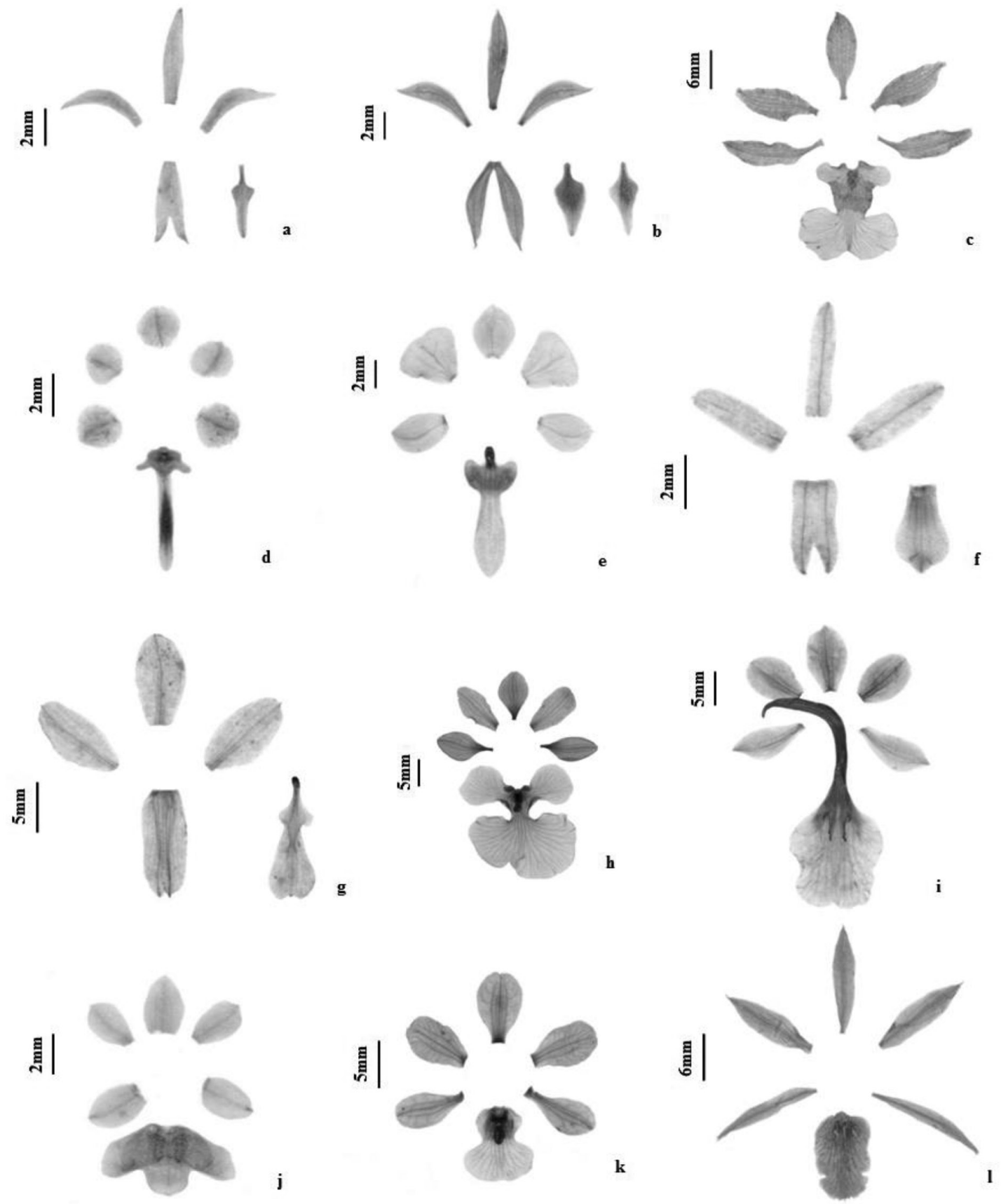

Figure 3. (a-1) Perianth pieces of Oncidiinae (Orchidaceae) species from the Great Curve of Xingu River. (a) Notylia yauaperyensis Barb.Rodr. (b) Notylia sp. (c) Oncidium baueri Lindl. (d) Ornithocephalus bicornis Lindl. (e) Ornithocephalus gladiatus Hook. (f) Quekettia microscopica Lindl. (g) Rodriguezia lanceolata Ruiz \& Pav. (h) Trichocentrum cebolleta (Jacq.) M.W.Chase \& N.H.Williams. (i) Trichocentrum fuscum Lindl. (j) Trichocentrum morenoi (Dodson \& Luer) M.W.Chase \& N.H.Williams. (k) Trichocentrum nanum (Lindl.) M.W.Chase \& N.H.Williams. (1) Trichopilia mutica (Lindl.) Rchb.f. \& Wullschl. 
Oncidium baueri is a widespread species and occurs in México, Panama, West Indies, Venezuela, Guianas, Brazil, Bolivia, Colombia, Argentina. In Brazil, it was recorded in the states of Amazonas, Amapá, Pará, Maranhão, Espírito Santo, Minas Gerais, Rio de Janeiro and São Paulo (Dunsterville and Garay, 1965; Pabst and Dungs, 1977; Silva et al., 1995; Barros et al., 2014). In the study area, it was found in evergreen riverine forests, blooming in January and August.

It can be distinguished among other Oncidiinae in the study area by its robust and dense habit and three to five distichous leaves embracing the ellipsoid pseudobulbs. Inflorescences can reach $2 \mathrm{~m}$ long, and the flowers are vivid yellow, resembling those of Trichocentrum cebolleta.

Additional illustrations: Congniaux (1906, tab. 85) and Dunsterville and Garay (1979, p. 645).

Ornithocephalus bicornis Lindl. in G.Bentham, Bot. Voy. Sulphur: 172 (1846) (Figure 3d.)

Plants 6-8 cm long; caulome not thickened into pseudobulb. Leaves 1.5-3 × 0.6-0.9 cm, ensiform, oblanceolate, ceraceous green, apex acute, oblique. Inflorescence a raceme, $4-8 \mathrm{~cm}$ long, axillary, ca. 30-flowered; peduncle 2-3.5 cm long. Flowers ca. $0.4 \mathrm{~cm}$ wide; pedicel plus ovary ca. $2 \mathrm{~mm}$ long; dorsal sepal ca. $2 \times 2 \mathrm{~mm}$, orbicular, cymbiform, translucent white, apex rounded, slightly apiculate; lateral sepals ca. $2 \times 2 \mathrm{~mm}$, orbiculate, subcymbiform, free, translucent white, apex rounded, slightly apiculate; petals ca. $2 \times 2 \mathrm{~mm}$, suborbiculate, translucent white, apex rounded, slightly apiculate; labellum ca. $6 \times 2.5 \mathrm{~mm}$, calcar absent, 3 -lobed, white translucent, green in the center, callus with subglobose callus; column ca. $1 \mathrm{~mm}$ long, inconspicuous, clinandrium margins lacerate; pollinia 4. Fruit not seen.

Specimens examined: Brazil. Pará: Senador José Porfírio, UHE Belo Monte, Rio Bacajá, margem esquerda, 23-05-2012, fl., PSACF 247 (MG).

Ornithocephalus bicornis is distributed in Southern Mexico (Govaerts et al., 2014), Panama, Venezuela, Colombia, Ecuador and Brazil (Dunsterville and Garay, 1961). In Brazil, it occurs in the North region in the states of Amazonas, Pará and Rondônia (Barros et al., 2014). It is quite rare in the study area, where it was found growing in secondary forests, blooming in May, July and August.

Ornithocephalus bicornis is characterised by its ensiform and equitant leaves, florescence with peduncle and flowers strongly pilose, and cordate bracts.

Additional illustrations: Dunsterville and Garay (1979, p. 688).

Ornithocephalus gladiatus Hook., Exot. Fl. 2: t. 127 (1824) (Figure 3e).

Plants 2-5 cm long; caulome not thickened into pseudobulb. Leaves 1.4-4 × 0.6-1 cm, ensiform, oblanceolate, ceraceous green, apex acute, oblique. Inflorescence a raceme, 4-7 cm long, axilar, 6-20-flowered; peduncle 2-4 cm long. Flowers ca. $0.8 \mathrm{~cm}$ wide; pedicel plus ovary ca. $4 \mathrm{~mm}$ long; dorsal sepal ca. $3 \times 3 \mathrm{~mm}$, suborbicular, cymbiform, greenish-white, apex subobtuse, subapiculate; lateral sepals ca. $3.8 \times 2.5 \mathrm{~mm}$, suboblongate or obovate, oblique, free, greenish-white, apex obtuse in adaxial surface and apiculate in abaxial surface; petals ca. $3.8 \times 4 \mathrm{~mm}$, obtriangular, translucent white, apex truncate; labellum ca. $7 \times 3 \mathrm{~mm}$, calcar absent, 3-lobed, white translucent, greenish-yellow at base, callus with conspicuous trichomes and papillae; column ca. $1 \mathrm{~mm}$ long, inconspicuous, clinandrium margins entire; pollinia 4. Fruit not seen.

Specimens examined: Brazil. Pará: Vitória do Xingu, UHE Belo Monte, Sítio Pimental, 08-12-2011, fl., PSACF 40 (MG); ibid., Sítio Belo Monte, 06-07-2012, fl., PSACF 526 (MG).

Ornithocephalus gladiatus occurs in Mexico, Honduras, Guatemala, Costa Rica, Panama, Trinidad, Tobago, Venezuela, Guiana, Suriname, Brazil, Colombia, Peru, Bolivia (Dunsterville and Garay, 1965) and Antilles (Pabst and Dungs, 1977). In Brazil, it was recorded in Amazonas, Pará, Maranhão, Ceará and Goiás (Pabst and Dungs, 1977; Barros et al., 2014). It was found with flowers in the study area in July, August and September.

It differs from $O$. bicornis by its sepals with papillae on the margins and callus of labellum with trichomes and papillae.

Additional illustrations: Congniaux (1905, tab. 45, fig. II) and Dunsterville and Garay (1979, p. 690).

Quekettia microscopica Lindl., Edwards's Bot. Reg. 25(Misc.): 3 (1839) (Figure 3f).

Plants 10-15 cm long; caulome slightly thickened into pseudobulb, $0.6-1 \times 0.3-0.6 \mathrm{~cm}$, cylindrical, not laterally compressed, apex 1-foliate. Leaves 4-12 × 0.2-0.4 cm, terete, with 1 longitudinal groove, green with brown spots, apex acute or acuminate. Inflorescence a panicle, 10-23 cm long, lateral, 8-25-flowered; peduncle 3-7 cm long. Flowers ca. $0.4 \mathrm{~cm}$ wide; pedicel plus ovary 3-5 mm long; dorsal sepal ca. $4.5 \times 1.5 \mathrm{~mm}$, linear-lanceolate, yellow, apex acute, subapiculate; lateral sepals ca. $4 \times 2 \mathrm{~mm}$, linear-lanceolate, connate at the $2 / 3$ basal portion in a tubular structure, yellow, apex acute, subapiculate; petals ca. $4.5 \times 1.8 \mathrm{~mm}$, linear-oblong, yellow, apex acuminate or subapiculate; labellum ca. $4 \times 2 \mathrm{~mm}$, slightly calcarate, 3-lobed, yellow with three red lines at apex, callus with small papillae at base; column ca. $3 \mathrm{~mm}$ long, subterete, clinandrium margins entire; pollinia 2. Fruit not seen.

Specimens examined: Brazil. Pará: Vitória do Xingu, UHE Belo Monte, Sítio Pimental, 13-01-2012, fl., PSACF 55 (MG).

This species occurs from northern South America to Northeastern Brazil (Govaerts et al., 2014). In Brazil, it was recorded in the states of Amazonas, Pará, Roraima and Maranhão (Pabst and Dungs, 1977; Barros et al., 2014). In the study area it is a rare species, and was collected growing on evergreen riverine forests blooming in January and February.

Quekettia microscopica is characterised by its terete leaves, a paniculate inflorescence with a thin peduncle, yellow flowers and lateral sepals fused at the base, in a tubular structure.

Additional illustrations: Congniaux (1904, tab. 34, fig. II), Hoehne (1949, tab. 246, fig. I) and Rodrigues et al. (1996, tab. 310, fig. A). 
Rodriguezia lanceolata Ruiz \& Pav., Syst. Veg. Fl. Peruv. Chil.1: 219 (1798) (Figure 3g).

Plants 10-20 cm long; caulome thickened into pseudobulb, 2-4.5 $\times 1.8-2 \mathrm{~cm}$, ellipsoid, laterally compressed, apex 1-foliate. Leaves 13-16 × 2-2.8 cm, flat, lanceolate or oblong, green, apex acute or acuminate. Inflorescence a raceme, 10-30 cm long, lateral, 16-35-flowered; peduncle $5-20 \mathrm{~cm}$ long. Flowers ca. $1.6 \mathrm{~cm}$ wide; pedicel plus ovary 10-12 mm long; dorsal sepal ca. $10 \times 7 \mathrm{~mm}$, obovate to elliptic, cymbiform, pinkish or red, apex subobtuse, subapiculate; lateral sepals ca. $11 \times 6 \mathrm{~mm}$, oblong, connate, pinkish or red, apex retuse; petals ca. $11 \times 5 \mathrm{~mm}$, obovate or elliptic, pinkish or red, apex obtuse, subapiculate; labellum ca. $12 \times 5 \mathrm{~mm}$, slightly calcarate, 4-lobed, pinkish or red, slightly yellow at base, callus with four longitudinal lamellae; column ca. $7 \mathrm{~mm}$ long, claviform, clinandrium margins entire; pollinia 2. Fruit not seen.

Specimens examined: Brazil. Pará: Vitória do Xingu, UHE Belo Monte, Sítio Pimental, 04-11-2011, fl., PSACF 14 (MG); ibid., Sítio Belo Monte, 29-11-2011, fl., PSACF 31(MG).

This species is distributed from the Antilles to Tropical America (Govaerts et al., 2014). In Brazil, it is known to occur in the states of Acre, Amazonas, Amapá, Pará, Rondônia, Roraima, Tocantins, Maranhão and Mato Grosso (Pabst and Dungs, 1977; Barros et al., 2014), and was found with flowers in the study area from January to March and November.

Rodriguezia lanceolata can be easily recognized among the Oncidiinae in the study area by the set of following characters: pendent racemose inflorescences, flowers around $16 \mathrm{~mm}$ wide, pink to reddish, and have lateral sepals completely adnate with the base of the column, forming a noticeable calcar.

Additional illustrations: Congniaux (1904, tab. 40, fig. II), Hoehne (1949, tab. 241) and Dunsterville and Garay (1979, p. 901).

Trichocentrum cebolleta (Jacq.) M.W.Chase \& N.H.Williams, Lindleyana 16: 137 (2001) (Figure 3h).

Plants 15-80 cm long; caulome thickened into pseudobulb, $1-2 \times 0.8-1.8 \mathrm{~cm}$, globose, not laterally compressed, apex 1-foliate. Leaves $14-80 \times 0.8-1.7 \mathrm{~cm}$, terete, with 1 longitudinal groove, green, apex acute. Inflorescence a panicle, 40-180 cm long, lateral, 15-90-flowered; peduncle $12-50 \mathrm{~cm}$ long. Flowers ca. $3 \mathrm{~cm}$ wide; pedicel plus ovary 20-25 mm long; dorsal sepal ca. $10 \times 7 \mathrm{~mm}$, obovate, cymbiform, yellow with purplish maculae, apex obtuse; lateral sepals ca. $12 \times 6 \mathrm{~mm}$, obovate, subcymbiform, free, yellow with purplish maculae, apex subobtuse; petals ca. $11 \times 5 \mathrm{~mm}$, oblanceolate or obovate, yellow with purplish maculae, apex subobtuse or subtruncate; labellum ca. $24 \times 23 \mathrm{~mm}$, calcar absent, 4-lobed, yellow with purple maculae at base, callus with three high keels; column ca. $5 \mathrm{~mm}$ long, claviform, clinandrium margins entire; pollinia 2. Fruit not seen.

Specimens examined: Brazil. Pará: Vitória do Xingu, UHE Belo Monte, 07-12-2011, fl., PSACF 763, (MG); ibid., Sítio Pimental, 27-12-2011, fl., PSACF 46 (MG); ibid., Sítio Pimental, 13-01-2012, fl., PSACF 54 (MG); ibid., Sítio Pimental, 04-10-2012, fl., PSACF 744 (MG); ibid., AID, 01-08-2013, fl., PSACF 20130801.13H06 (MG); ibid., Canais e Diques, 04-09-2013, fl., PSACF 20130904.10H02 (MG).

This species is widely distributed around Central America, Suriname, Argentina and Brazil (Pabst and Dungs, 1977). In Brazil, there are records for the states of Acre, Amazonas, Amapá, Pará, Rondônia, Roraima, Tocantins, Alagoas, Bahia, Ceará, Maranhão, Paraíba, Pernambuco, Piauí, Rio Grande do Norte, Sergipe, Distrito Federal, Goiás, Mato Grosso do Sul, Mato Grosso, Espírito Santo and Minas Gerais (Silva et al., 1995; Barros et al., 2014). In the study area, it is a common species typical of forest formations. It was found blooming in January, July, August, September, October and December.

Trichocentrum cebolleta can be easily distinguished by its terete leaves, a large inflorescence with shiny-yellow flowers with purple maculae on the base of petals and sepals. Additional illustrations: Congniaux (1906, tab. 92, fig. I), Hoehne (1949, tab. 51) and Dunsterville and Garay (1979, p. 649).

Trichocentrum fuscum Lindl., Edwards's Bot. Reg. 23: t. 1951 (1837) (Figure 3i).

Plants 7-12 cm long; caulome slightly thickened into pseudobulb, $0.5-1 \times 0.3-0.5 \mathrm{~cm}$, oblongoid, not laterally compressed, apex 1-foliate. Leaves 6-11 × 1.8-2.5 cm, flat, oblong or elliptic, green with reddish-brown spots, apex acute or acuminate. Inflorescence a raceme, $3-5 \mathrm{~cm}$ long, lateral, 1-3-flowered; peduncle $1.5-2.5 \mathrm{~cm}$ long. Flowers $0.8-1.5 \mathrm{~cm}$ wide; pedicel plus ovary $18-30 \mathrm{~mm}$ long; dorsal sepal 10-13 × 7-8 mm, obovate to elliptic, cymbiform, brownish-yellow, apex subobtuse, subapiculate; lateral sepals ca. $8 \times 5 \mathrm{~mm}$, suboblongate, oblique, free, brownish-yellow, apex acuminate; petals 17-20 × 12-15 mm, obovate or elliptic, brownish-yellow, apex rounded, abaxially apiculate; labellum 17-20 × 12-15 mm, tubuliform calcar, inflexuous, 4-lobed, white, yellow or purple at base, callus with four longitudinal keels; column ca. $8 \mathrm{~mm}$ long, claviform, clinandrium margins entire; pollinia 2. Fruit ca. $3 \times 1.3 \mathrm{~cm}$, fusiform.

Specimens examined: Brazil. Pará: Vitória do Xingu, UHE Belo Monte, Sítio Pimental, 12-06-2012, fl., PSACF 351(MG); ibid., Sítio Canais e Diques, 17-11-2011, fl., PSACF 26 (MG); ibid., Sítio Canais e Diques, 06-05-2013, fl., PSACF 1217 (MG).

This species if distributed from Mexico (Pabst and Dungs, 1977) to southern Tropical America (Govaerts et al., 2014). In Brazil, it is widespread, with records for Amazonas, Pará, Roraima, Alagoas, Bahia, Ceará, Pernambuco, Sergipe, Goiás, Mato Grosso, Espírito Santo, Minas Gerais, Rio de Janeiro, Paraná and Santa Catarina states (Pabst and Dungs, 1977; Barros et al., 2014). It is a common species in the study area, where it was found growing in secondary forests, blooming in January, February, June, August, September and November. 
Trichocentrum fuscum is characterised by its obovate to oblong and erect-patent labellum, with base adnate to the column, in a tubular and strongly inflexed calcar.

Additional illustrations: Hoehne (1949, tab. 234) and Dunsterville and Garay (1979, p. 1020).

Trichocentrum morenoi (Dodson \& Luer) M.W.Chase \& N.H.Williams, Lindleyana 16: 138 (2001) (Figure 3j).

Plants 4-9 cm long; caulome slightly thickened into pseudobulb, ca. $0.4 \times 0.4 \mathrm{~cm}$, globose, not laterally compressed, apex 1-foliate. Leaves 2.5-8 × 1-2 cm, flat, oblong or elliptic, green with purplish-brown spots, apex acute or acuminate. Inflorescence a panicle, $3-10 \mathrm{~cm}$ long, lateral, 20-120-flowered; peduncle 1.2-3 cm long. Flowers ca. $0.6 \mathrm{~cm}$ wide; pedicel plus ovary ca. $3 \mathrm{~mm}$ long; dorsal sepal ca. $3 \times 2 \mathrm{~mm}$, subovate to suborbicular, cymbiform, whitish, apex subacute; lateral sepals ca. $3 \times 2 \mathrm{~mm}$, suboblongate or subovate, free, whitish, apex subacute; petals ca. $3 \times 2 \mathrm{~mm}$, obovate, whitish, apex subobtuse, subapiculate; labellum ca. 4-7 mm, calcar absent, 3-lobed, withish, yellowish at base, callus longitudinal queued wards, pilose; column ca. $1 \mathrm{~mm}$ long, inconspicuous, clinandrium margins entire; pollinia 2. Fruit ca. $0.8 \times 0.5 \mathrm{~cm}$, ellipsoid.

Specimens examined: Brazil. Pará: Vitória do Xingu, UHE Belo Monte, Sítio Pimental, 28-05-2012, fr., PSACF 268 (MG); ibid., Sítio Pimental, 30-08-2012, fl., PSACF 702 (MG); ibid., Sítio Canais e Diques, 17-10-2011, fl., PSACF 24 (MG); ibid., Sítio Canais e Diques, 15-02-2013, fl., PSACF 842 (MG); ibid., Sítio Canais e Diques, 30-07-2013, fl., PSACF 20130730.13H03 (MG); ibid., Sítio Canais e Diques, 22-08-2013, fl., PSACF 20130822.10H01 (MG).

Trichocentrum morenoi is distributed in Brazil, Peru and Bolívia (Govaerts et al., 2014). In Brazil, it occurs in Pará, Tocantins, Maranhão, Mato Grosso, Mato Grosso do Sul, Espírito Santo and São Paulo (Pabst and Dungs, 1977; Silva et al., 1995; Barros et al., 2014). It was found in the study area growing in evergreen riverine forests and secondary forests, blooming in February, May, July, August, September, October and November.

This species differs from the other Orchidaceae in the study area by its inflorescence with a tough peduncle and a congested multi-flowered panicle, bearing flowers $6 \mathrm{~mm}$ wide, with white sepals and petals and yellow labellum callus.

Trichocentrum nanum (Lindl.) M.W.Chase \& N.H.Williams, Lindleyana 16: 138 (2001) (Figure 3k).

Plants 8-23 cm long; caulome slightly thickened into pseudobulb, $0.4-0.6 \times 0.3-0.5 \mathrm{~cm}$, globose, not laterally compressed, apex 1-foliate. Leaves 8-20 × 2-4 cm, flat, oblong or elliptic, green with brown spots, apex acute or acuminate. Inflorescence a raceme, $6-13 \mathrm{~cm}$ long, lateral, 8-25-flowered; peduncle $4-7 \mathrm{~cm}$ long. Flowers ca. $1.4 \mathrm{~cm}$ wide; pedicel plus ovary ca.10-12 mm long; dorsal sepal ca. $6 \times 4 \mathrm{~mm}$, obovate, cymbiform, yellow with red maculae, apex rounded; lateral sepals ca. $7 \times 3 \mathrm{~mm}$, oblanceolate, free, yellow with red maculae, apex rounded; petals ca. $6 \times 4 \mathrm{~mm}$, obovate, yellow with red maculae, apex rounded or retuse; labellum ca. $7 \times 7 \mathrm{~mm}$, calcar absent, 3-lobed, yellow, reddish at base, callus with high globose callus; column ca. $4 \mathrm{~mm}$ long, inconspicuous, clinandrium margins entire; pollinia 2. Fruit not seen.

Specimens examined: Brazil. Pará: Vitória do Xingu, UHE Belo Monte, Sítio Pimental, 24-05-2012, fl., PSACF 261 (MG); ibid., Sítio Pimental, 24-09-2012, fl., PSACF 20120924.06H02 (MG); ibid., Sítio Canais e Diques, 26-12-2011, fl., PSACF 45 (MG).

This species occurs in Southern Tropical America (Govaerts et al., 2014), including French Guiana, Venezuela, Bolivia, Colombia, Ecuador, Peru and Brazil (Dunsterville and Garay, 1959; Pabst and Dungs, 1977; Govaerts et al., 2014). In Brazil, it is distributed in the states of Amazonas, Pará, Rondônia, Roraima, Tocantins, Maranhão, Mato Grosso do Sul and Mato Grosso (Pabst and Dungs, 1977; Silva et al., 1995; Barros et al., 2014). In the study area, it was collected in evergreen riverine forests and secondary forests, where it was found with flowers in May, August, September and December.

Both Trichocentrum nanum and T. morenoi are quite similar in vegetative characters, but can be easily distinguished by its inflorescences and flowers. Trichocentrum nanum has a racemose inflorecence with 8-24 flowers, with are wider $14 \mathrm{~mm}$, yellow with purple maculate on the petals and sepals and has a distinctive globose callus. In turn, T. morenoi has a short and erect panicle, with flowers smaller (ca. $6 \mathrm{~mm}$ wide), petals and sepals white and a yellow callus.

Additional illustrations: Hoehne (1949, tab. 49), Rodrigues et al. (1996, tab. 262) and Dunsterville and Garay (1979, p. 668).

Trichopilia mutica (Lindl.) Rchb.f. \& Wullschl. in W.G.Walpers, Ann. Bot. Syst. 6: 679 (1863) (Figure 31).

Plants 15-20 cm long; caulome thickened into pseudobulb, ca. $2 \times 0.6 \mathrm{~cm}$, cylindrical, not laterally compressed, apex 1-foliate. Leaves 7.5-16 × 0.6-1.2 cm, flat, linear-lanceolate, green, apex acuminate. Inflorescence a raceme, ca. $7 \mathrm{~cm}$ long, lateral, 3-5-flowered; peduncle ca. $3 \mathrm{~cm}$ long. Flowers ca. $2 \mathrm{~cm}$ wide; pedicel plus ovary ca. $7 \mathrm{~mm}$ long; dorsal sepal ca. $14 \times 3 \mathrm{~mm}$, lanceolate, pale yellow translucent, apex acuminate; lateral sepals ca. $15 \times 3 \mathrm{~mm}$, linear-lanceolate, free, pale yellow translucent, apex acuminate, apiculate; petals ca. $12 \times 4 \mathrm{~mm}$, oblanceolate, pale yellow translucent, apex acuminate; labellum ca. $11 \times 7 \mathrm{~mm}$, calcar absent, 3-lobed or entire, cucculate at base, withish with pink spots, callus with triangular lamella; column ca. $7 \mathrm{~mm}$ long, subterete, clinandrium margins fimbriate; pollinia 2. Fruit ca. $2 \times 1.2 \mathrm{~cm}$, ellipsoid.

Specimens examined: Brazil. Pará: Vitória do Xingu, UHE Belo Monte, Sítio Belo Monte, 15-04-2013, fl., PSACF 1035 (MG).

In South America, with distribution in Venezuela and Brazil (Govaerts et al., 2014). This species occurs in the states of Amazonas, Pará and Maranhão, Brazil (Silva et al., 1995; Barros et al., 2014). In the study area, it was collected growing in secondary forests, blooming in April.

Trichopilia mutica is characterised by its cylindrical pseudobulbs, leaves linear-lanceolate, coriaceous and 
sulcate longitudinally, inflorescence with five flowers or less, petals and sepals whitish, labellum transluscent white with pink spots and base strongly concave, undulated margin and apiculate apex.

Additional illustrations: Congniaux (1905, tab. 43, fig. I).

\section{Acknlowledgements}

The authors thank the Norte Energia S.A.company for the permission to access the study area and for the logistics during fieldwork of the project Survey and scientific exploitation of the Flora of the UHE Belo Monte, which is part of the Environment Basic Plan of the Norte Energia S.A. company; the Postgraduate Program in Biological Sciences - Tropical Botany from UFRA/MPEG; the CNPq for the scholarship provided to the first and second authors. This work is part of the dissertation of the first author.

\section{References}

AB'SÁBER, AN., 1996. Amazônia, do discurso à práxis. São Paulo: Edusp. 318 p.

BARROS, F., VINHOS, F., RODRIGUES, VT., BARBERENA, FFVA., FRAGA, CN., PESSOA, EM., FORSTER, W and MENINI NETO, L., 2014. Orchidaceae in lista de espécies da Flora do Brazil. Jardim Botânico do Rio de Janeiro. Available from: $<$ http://floradobrasil.jbrj.gov.br/jabot/floradobrasil/FB179>. Access in: 06 Jan. 2014.

BRUMMITT, RK. and POWELL, CE. (Eds.), 1992. Authors of plant names. A list of authors of scientific names of plants, with recommended standard forms of their names, including abbreviations. Richmond: Royal Botanic Gardens, Kew. 732 p.

CARDOSO, ALR., ILKIU-BORGES, AL. and SUEMITSU, C., 1995. Flora orquidológica da Ilha do Combu, município de Acará - Pará. Boletim do Museu Paraense Emílio Goeldi. Série Botânica, vol. 11, no. 2, p. 231-238.

CHASE, MW., CAMERON, KM., BARRETT, RL. and FREUDENSTEIN, JV., 2003. DNA data and Orchidaceae systematics: a new phylogenetic classification. In DIXON, KW., KELL, SP., BARRETT, RL. and CRIBB, PJ. (Eds). Orchid conservation. Kota Kinabalu: Natural History Publications. p. 69-89.

CHASE, MW., HANSON, L., ALBERT, VA., WHITTEN, WM. and WILLIAMS, NH., 2005. Life history evolution and genome size in subtribe Oncidiinae (Orchidaceae). Annals of Botany, vol. 95, no. 1, p. 191-199. http://dx.doi.org/10.1093/aob/mci012. PMid:15596466.

CHASE, MW., WILLIAMS, NH., FARIA, AD., NEUBIG, KM., AMARAL, MC. and WHITTEN, WM., 2009. Floral convergence in Oncidiinae (Cymbidieae; Orchidaceae): an expanded concept of Gomesa and a new genus Nohawilliamsia. Annals of Botany, vol. 104, no. 3, p. 387-402. http://dx.doi.org/10.1093/aob/mcp067. PMid:19346522.

CONGNIAUX, A., 1893-1896. Orchidaceae. In MARTIUS, CFP., EICHLER, AG. and URBAN, I. (Eds.). Flora brasiliensis. Monachii: Typographia Regia. 672 p.

CONGNIAUX, A., 1898-1902. Orchidaceae. In MARTIUS, CFP., EICHLER, AG. and URBAN, I. (Eds.). Flora brasiliensis. Monachii: Typographia Regia. 663 p.
CONGNIAUX, A., 1904. Orchidaceae. In MARTIUS, CFP., EICHLER, AG. and URBAN, I. (Eds.). Flora brasiliensis. Monachii: R. Oldenbourg.

CONGNIAUX, A., 1905. Orchidaceae. In MARTIUS, CFP., EICHLER, AG. and URBAN, I. (Eds.). Flora brasiliensis. Monachii: R. Oldenbourg.

CONGNIAUX, A., 1906. Orchidaceae. In MARTIUS, CFP., EICHLER, AG. and URBAN, I. (Eds.). Flora brasiliensis. Monachii: R. Oldenbourg.

DRESSLER, RL., 1993. Phylogeny and classification of the orchid family. Portland: Dioscorides Press. 314 p.

DUNSTERVILLE, GCK. and GARAY, LA., 1959. Venezuelan orchids illustrated. London: Andre Deutsch. vol. 1, 448 p.

DUNSTERVILLE, GCK. and GARAY, LA., 1961. Venezuelan orchids illustrated. London: Andre Deutsch. vol. 2, 360 p.

DUNSTERVILLE, GCK. and GARAY, LA., 1965. Venezuelan orchids illustrated. London: Andre Deutsch. vol. 3, 463 p.

DUNSTERVILLE, GCK. and GARAY, LA., 1972. Venezuelan orchids illustrated. London: Andre Deutsch. vol. 5, 337 p.

DUNSTERVILLE, GCK. and GARAY, LA., 1979. Orchids of Venezuela. An illustrated field guide. London: Andre Deutsch. 333 p.

GONÇALVES, EG. and LORENZI, H., 2011. Morfologia Vegetal: organografia e dicionário ilustrado de morfologia de plantas vasculares. São Paulo: Instituto Plantarum de Estudos da Flora. 544 p.

GOVAERTS, R., BERNET, P., KRATOCHVIL, K., GERLACH, G., CARR, G., ALRICH, P., PRIDGEON, AM., PFAHL, J., CAMPACCI, MA., BAPTISTA, DH., TIGGES, H., SHAW, J., CRIBB, P., GEORGE, A., KREUZ, K. and WOOD, J., 2014. World checklist of Orchidaceae. Richmond: Royal Botanic Gardens, Kew. Available from: <http://apps.kew.org/wcsp/>. Access in: 06 Jan. 2014.

HOEHNE, FC., 1949. Iconografia das Orchidaceae do Brasil. São Paulo: Secretaria da Agricultura, Indústria e Comércio. 302 p.

ILKIU-BORGES, AL. and CARDOSO, ALR., 1996. Notas preliminares sobre a flora orquidológica do Estado do Pará, Brasil. Boletim Museu Paraense Emilio Goeldi. Série Botânica, vol. 12, no. 2, p. 183-205.

KOCH, AK., SANTOS, JUM. and ILKIU-BORGES, AL., 2014. Sinopse das Orchidaceae holoepífitas e hemiepífitas da Floresta Nacional de Caxiuanã, Pará, Brasil. Hoehnea, vol. 21, no. 1, p. 129-148.

MEDEIROS, TDS., QUARESMA, AC. and SILVA, JBF., 2009. As orquídeas. In JARDIM, MAG. (Org.). Diversidade biológica das áreas de proteção ambiental Ilhas do Combu e AlgodoalMaiandeua, Pará, Brasil. Belém: Museu Paraense Emilio Goeldi. p. 41-59. Coleção Adolpho Ducke.

MEDEIROS, TDS. and JARDIM, MAG., 2011. Distribuição vertical de orquídeas epífitas na Área de Proteção Ambiental (APA) Ilha do Combu, Belém, Pará, Brasil. Revista Brasileira de Biociências, vol. 9, no. 1, p. 33-38.

NEUBIG, KM., WHITTEN, WM., WILLIAMS, NH., BLANCO, MA., ENDARA, L., BURLEIGH, JG., SILVERA, K., CUSHMAN, JC. and CHASE, MW., 2012. Generic recircumscriptions of Oncidiinae (Orchidaceae: Cymbidieae) based on maximum likelihood analysis of combined DNA datasets. Botanical Journal 
of the Linnean Society, vol. 168, no. 1, p. 117-146. http://dx.doi. org/10.1111/j.1095-8339.2011.01194.x.

PABST, GFJ. and DUNGS, F., 1975. Orchidaceae brasiliensis. Hildeshein: Brucke Verlag Kurt Schmersow. vol. 1, 408 p.

PABST, GFJ. and DUNGS, F., 1977. Orchidaceae brasiliensis. Hildeshein: Brucke-Verlag Kurt Schmersow. vol. 2, 418 p.

PAPADOPULOS, AS., POWELL, MP., PUPULIN, F., WARNER, J., HAWKINS, JA., SALAMIN, N., CHITTKA, L., WILLIAMS, NH., WHITTEN, WM., LOADER, D., VALENTE, LM., CHASE, MW. and SAVOLAINEN, V., 2013. Convergent evolution of floral signals underlies the success of Neotropical orchids. Proceedings. Biological sciences / The Royal Society, vol. 280, no. 1765, p. 20130960. http://dx.doi.org/10.1098/rspb.2013.0960. PMid:23804617.

PENHA, TLL. and CATHARINO, ELM., 2010. Binotia messmeriana e seu posicionamento taxonômico. Boletim $C A O B$, vol. $77-78$, p. 16-19.

RADFORD, AE., DICKISON, WC., MASSEY, JR. and BELL, CR., 1974. Vascular plant systematics. New York: Harper \& Row. 891 p.

RODRIGUES, JB., 1877. Genera et species Orchidearum Novarum.Rio de Janeiro: Typographia Nacional. vol. 1, 206 p.

RODRIGUES, JB., 1882. Genera et Species Orchidearum Novarum.Rio de Janeiro: Typographia Nacional. vol. 2. 295 p.

RODRIGUES, JB., SPRUNGER, S. and CRIBB, P., 1996. Iconographie des orchidées du Brésil: the illustrations. Basle: Friedrich Reinhardt Verlag. vol. 1, 540 p.

SALOMÃO, RP., VIEIRA, ICG., SUEMITSU, C., ROSA, NA., ALMEIDA, SS., AMARAL, DD. and MENEZES, MPM., 2007. As florestas de Belo Monte na grande curva do rio Xingu, Amazônia Oriental. Belém. Boletim do Museu Paraense Emílio Goeldi-Ciências Naturais, vol. 2, no. 3, p. 57-153.
SILVA, MFF. and SILVA, JBF., 2011. Orquideas nativas da Amazônia Brasileira II. 3th. ed. Belém: Museu Paraense Emílio Goeldi/Universidade Federal Rural da Amazônia. 528 p.

SILVA, MFF., SILVA, JBF., ROCHA, AES., OLIVEIRA, FPM., GONÇALVES, LSB., SILVA, MF. and QUEIROZ, OHA., 1995. Inventário da família Orchidaceae na Amazônia brasileira. Parte I. Acta Botanica Brasílica, vol. 9, no. 1, p. 163-175. http://dx.doi. org/10.1590/S0102-33061995000100009.

SILVEIRA, EC., CARDOSO, ALR., ILKIU-BORGES, AL. and VON ATZINGEN, N., 1995. Flora orquidológica da Serra dos Carajás, Estado do Pará. Boletim Museu Paraense Emilio Goeldi. Série Botânica, vol. 11, no. 1, p. 75-87.

SOSA, V., CHASE, MW., SALAZAR, GE., WHITTEN, WM. and WILLIAMS, NH., 2001. Phylogenetic position of Dignathe (Orchidaceae: Oncidiinae): evidence from nuclear ITS ribosomal DNA sequences. Lindleyana, vol. 16, no. 1, p. 94-101.

SOUSA JÚNIOR, WC., REID, J. and LEITÃO, NCS., 2006. Custos e beneficios do complexo hidrelétrico Belo Monte: Uma abordagem econômico-ambiental. Lagoa Santa: Conservation Strategy Fund - Conservação Estratégica. Série Técnica, no. 4.

VON ATZINGEN, N., CARDOSO, ALR. and ILKIU-BORGES, AL., 1996. Flora orquidológica da Serra das Andorinhas, São Geraldo do Araguaia-PA. Boletim do Museu Paraense Emílio Goeldi. Série Botânica, vol. 12, no. 1, p. 59-74.

WERKHOVEN, MCM., 1986. Orchids of suriname. Paramaribo: Vaco Uitgeversmaatschappij. 256 p.

WILLIAMS, NH., CHASE, MW., FULCHER, T. and WHITTEN, WM., 2001a. Molecular systematics of the Oncidiinae based on evidence from four DNA sequence regions: expanded circumscriptions of Cyrtochilum, Erycina, Otoglossum, and Trichocentrum and a new genus (Orchidaceae). Lindleyana, vol. 16, no. 2, p. 113-139.

WILLIAMS, NH., CHASE, MW. and WHITTEN, WM., $2001 \mathrm{~b}$. Phylogenetic positions of Miltoniopsis, Caucaea, a new genus, Cyrtochiloides, and Oncidium phymatochilum (Orchidaceae: Oncidiinae). Lindleyana, vol. 16, no. 1, p. 272-285. 